\title{
The evolving roles of canonical WNT signaling in stem cells and tumorigenesis: implications in targeted cancer therapies
}

\author{
Ke Yang ${ }^{1,2,3}$, Xin Wang ${ }^{2,4}$, Hongmei Zhang ${ }^{2,5}$, Zhongliang Wang ${ }^{1,2}$, Guoxin Nan ${ }^{1,2}$, Yasha Li ${ }^{1,2}$, Fugui Zhang ${ }^{2,5}$, \\ Maryam K Mohammed ${ }^{2}$, Rex C Haydon', Hue H Luu', Yang Bi ${ }^{1,2}$ and Tong-Chuan He $\mathrm{H}^{1,2,5}$
}

The canonical WNT/ $\beta$-catenin signaling pathway governs a myriad of biological processes underlying the development and maintenance of adult tissue homeostasis, including regulation of stem cell self-renewal, cell proliferation, differentiation, and apoptosis. WNTs are secreted lipid-modified glycoproteins that act as short-range ligands to activate receptor-mediated signaling pathways. The hallmark of the canonical pathway is the activation of $\beta$-catenin-mediated transcriptional activity. Canonical WNTs control the $\beta$-catenin dynamics as the cytoplasmic level of $\beta$-catenin is tightly regulated via phosphorylation by the 'destruction complex', consisting of glycogen synthase kinase $3 \beta$ (GSK3 $\beta$ ), casein kinase 1a (CK1a), the scaffold protein AXIN, and the tumor suppressor adenomatous polyposis coli (APC). Aberrant regulation of this signaling cascade is associated with varieties of human diseases, especially cancers. Over the past decade, significant progress has been made in understanding the mechanisms of canonical WNT signaling. In this review, we focus on the current understanding of WNT signaling at the extracellular, cytoplasmic membrane, and intracellular/ nuclear levels, including the emerging knowledge of cross-talk with other pathways. Recent progresses in developing novel WNT pathway-targeted therapies will also be reviewed. Thus, this review is intended to serve as a refresher of the current understanding about the physiologic and pathogenic roles of WNT/ $\beta$-catenin signaling pathway, and to outline potential therapeutic opportunities by targeting the canonical WNT pathway.

Laboratory Investigation (2016) 96, 116-136; doi:10.1038/labinvest.2015.144; published online 30 November 2015

Originally identified as Int-1, the Wnt1 gene was discovered over 30 years ago as a gene activated by integration of mouse mammary tumor virus proviral DNA in virally induced breast tumors. ${ }^{1,2}$ An early identified fly Wingless (Wg) gene, which regulates segment polarity during larval development, ${ }^{3}$ was found to be a WNT1 homolog. ${ }^{4}$ In the following years, studies of Drosophila genetics delineating the relationships among segment polarity mutations mapped out the core of the WNT/Wg signal transduction cascade by identifying Porcupine (PORC), disheveled (DVL), armadillo ( $\beta$-catenin), and zeste-white 3/glycogen synthase kinase 3 (GSK3) genes. ${ }^{5-8} \mathrm{~A}$ fuller image of the WNT signaling pathway emerged when T-cell factor/lymphocyte enhancer factor (TCF/LEF) transcription factors were identified as WNT nuclear effectors ${ }^{9,10}$ and
Frizzleds (FZDs) were identified as WNT obligate receptors, ${ }^{11}$ functioning together with co-receptors, such as low-density lipoprotein-receptor-related proteins (LRPs)/Arrow. ${ }^{12}$ The first case for the involvement of WNT signaling in human cancers was made when the hereditary cancer syndrome termed familial adenomatous polyposis (FAP) gene product, adenomatous polyposis coli (APC), ${ }^{13,14}$ was found to interact with $\beta$-catenin, ${ }^{15,16}$ and was later shown to have a critical role in controlling $\beta$-catenin protein stability. For the past two decades, numerous components of this pathway and more disease connections have been uncovered. ${ }^{17-27}$

In most mammalian genomes, the WNT family is comprised of 19 members that are characterized by a highly conserved cysteine-rich secreted glycoproteins, which present

\footnotetext{
Stem Cell Biology and Therapy Laboratory, Ministry of Education Key Laboratory of Child Development and Disorders, The Children's Hospital, Chongqing Medical University, Chongqing, China; ${ }^{2}$ Molecular Oncology Laboratory, The University of Chicago Medical Center, Chicago, IL, USA; ${ }^{3}$ Chongqing Stem Cell Therapy Engineering and Technology Center, Chongqing, China; ${ }^{4}$ Department of Surgery, West China Hospital, Sichuan University, Chengdu, China and ${ }^{5}$ Chongqing Key Laboratory for Oral Diseases and Biomedical Sciences, and the Affiliated Hospital of Stomatology of Chongqing Medical University, Chongqing, China

Correspondence: Dr Y Bi, MD, PhD, Stem Cell Biology and Therapy Laboratory, Ministry of Education Key Laboratory of Child Development and Disorders, The Children's Hospital, Chongqing Medical University, Chongqing 400046, China or Dr T-C He, MD, PhD, Molecular Oncology Laboratory, The University of Chicago Medical Center, 5841 South Maryland Avenue, MC 3079, Chicago, IL 60637, USA.
}

E-mail: yangbi1981@cqmu.edu.cn or tche@uchicago.edu

Received 8 September 2015; accepted 6 October 2015 
the technical challenges in efficient production, biochemical characterization, and structural analysis of WNT proteins, ${ }^{28}$ although the structure of the Xenopus WNT8 protein as bound to Frizzled (FZD) was recently solved. ${ }^{29}$ The lipid components of WNTs are required for efficient signaling, including WNT protein secretion. ${ }^{30,31}$ WNT palmitoylation is essential for WNT signaling and is carried out by PORC, a dedicated ER-localized O-acyltransferase and highly conserved component of the WNT pathway. ${ }^{32,33}$ Loss of PORC leads to retention of WNT3A in the ER. ${ }^{34}$ Furthermore, WNT proteins are transported to the cell surface by the highly conserved integral membrane protein WNTLESS (WLS, also known as Evi, or GPR177), which is a transcriptional target of WNT signaling and has an important role during development. ${ }^{35-44}$ In most cell/tissue contexts, WNTs act as short-range signaling. ${ }^{23}$

The emerging evidence indicates that WNT signaling has an essential role in regulating many biological processes, including embryonic development, tissue homoeostasis, and maintenance of stem cells. Dysregulation of WNT signaling pathway is associated with various human diseases. ${ }^{17-27}$ Traditionally, WNT signaling is classified into two large categories: the canonical WNT (or $\beta$-catenin-dependent) and non-canonical WNT (or $\beta$-catenin-independent) pathways. Biologically, the canonical WNT/ $\beta$-catenin signaling pathway usually has crucial roles in regulating cell fate, proliferation, and survival, whereas the non-canonical WNT signaling is more associated with differentiation, cell polarity, and migration. ${ }^{25-27}$ Non-canonical WNT signaling can be initiated by WNT interaction with Frizzled receptors, or RYK and ROR receptor tyrosine kinases, and regulates small GTPases (such as RhoA, Rac, and Cdc42) in a DVL-dependent manner. Non-canonical WNT signaling can also activate calcium flux and kinase cascades, including protein kinase C (PKC), calcium/calmodulin-dependent protein kinase II (CaMKII), and JUN N-terminal kinase (JNK), leading to the activation of AP1- and NFAT-regulated gene expression. ${ }^{25-27}$ Increasing evidence indicates that the canonical and non-canonical pathways are intersecting signaling networks that coordinately regulate complex processes, such as embryonic development, stem cell maintenance, tissue homeostasis, and wound healing. ${ }^{27}$ In this review, we mainly focus on the canonical WNT/ $\beta$-catenin pathway in regulating stem cells and tumorigenesis, as well as potential anticancer therapeutic opportunities by targeting key steps of this signaling pathway.

\section{THE CANONICAL WNT/ $\beta$-CATENIN SIGNALING PATHWAY A Simplified Overview}

When specific WNT ligands are absent, cytoplasmic $\beta$-catenin is phosphorylated by the destruction complex formed by the three proteins: APC, AXIN, and GSK3 $\beta$ (Figure 1). Initial Casein Kinase 1 (CKI) phosphorylation occurs at Ser45, which primes the molecule for subsequent phosphorylation by GSK3 $\beta$ on Thr41, Ser37, and Ser33..$^{20,25}$ Phosphorylated $\beta$-catenin is recognized by E3 ubiquitin ligase $\beta$-Trcp, and degraded by ubiquitin proteasome pathway. Consequently, $\beta$-catenin in cytoplasm is kept at a low level. The nuclear transcription factor lymphoid enhancer-binding factor/T-cellspecific factor (LEF/TCF) is associated with Groucho and histone deacetylases, and represses the expression of WNT/ $\beta$-catenin target genes. ${ }^{45-47}$

WNT proteins interact with the seven transmembrane receptors of FZD family and single pass transmembrane co-receptors, such as low-density lipoprotein receptor-related protein 5/6 (LRP5/6) or receptor tyrosine kinase-like orphan receptor 2 (ROR2), to induce intracellular signaling pathway. WNT ligands bind to the cysteine-rich domain (CRD) of FZD and trigger LRP5/6 phosphorylation and the formation of FZD-LRP5/6 heterotrimeric complex. ${ }^{48}$ The activation of DVL protein is phosphorylated and translocate to the FZD receptor. ${ }^{49,50}$ In this context, the $\beta$-catenin destruction complex is disrupted, which prevents $\beta$-catenin proteasomal degradation. Stabilized $\beta$-catenin accumulates in the cytoplasm and is then translocated into the nucleus (Figure 1). Nuclear $\beta$-catenin displaces Groucho and forms a complex with the B-cell lymphoma 9 protein (BCL9), Pygopus, histone modifier CBP, as well as tissue-specific transcriptional activators, ${ }^{51,52}$ and binds to LEF/TCF proteins to regulate the expression of WNT target genes in a cell-typespecific manner. ${ }^{53-60}$

\section{DVL Has an Essential Switchboard Role in Channeling WNT Signaling}

The scaffold protein DVL is the key cytoplasmic partner of WNT signaling. DVL inhibits AXIN function through a direct interaction with the DIX domain of DVL, which is an important step in the activation of canonical WNT signal pathway. ${ }^{61}$ DVL is involved in the formation of the FZD and LRP6 complex. FZD recruits DVL by binding to the PDZ domain of DVL. WNT promotes DVL-dependent LRP6 phosphorylation to regulate downstream gene expression. ${ }^{48}$ Furthermore, DVL shuttles between the cytoplasm and the nucleus to transduce canonical WNT signaling to GSK3 $\beta$-destruction complex of $\beta$-catenin, resulting in the stabilization of $\beta$-catenin. ${ }^{62}$ The mutation in DVL nuclear localization signal domain leads to inhibition of the $\mathrm{WNT} / \beta$-catenin signaling. Nuclear DVL, c-Jun, and $\beta$-catenin form a complex leading to the stabilization of $\beta$-catenin/TCF interaction. Interestingly, DVL was also shown to interact with transcription factor Hipk1 to regulate the transcription of $\mathrm{WNT} / \beta$-catenin target genes. ${ }^{63}$ Forkhead box (FOX) transcription factors, FOXK1 and FOXK2, have been recently shown to positively regulate $\mathrm{WNT} / \beta$-catenin signaling by translocating DVL into the nucleus. ${ }^{64}$

\section{Stabilization and Nuclear Translocation of the $\beta$-Catenin Protein is the Essence of Canonical WNT Signaling}

As a dual function adhesion and transcription coactivator protein, $\beta$-catenin is a key mediator of the canonical WNT 


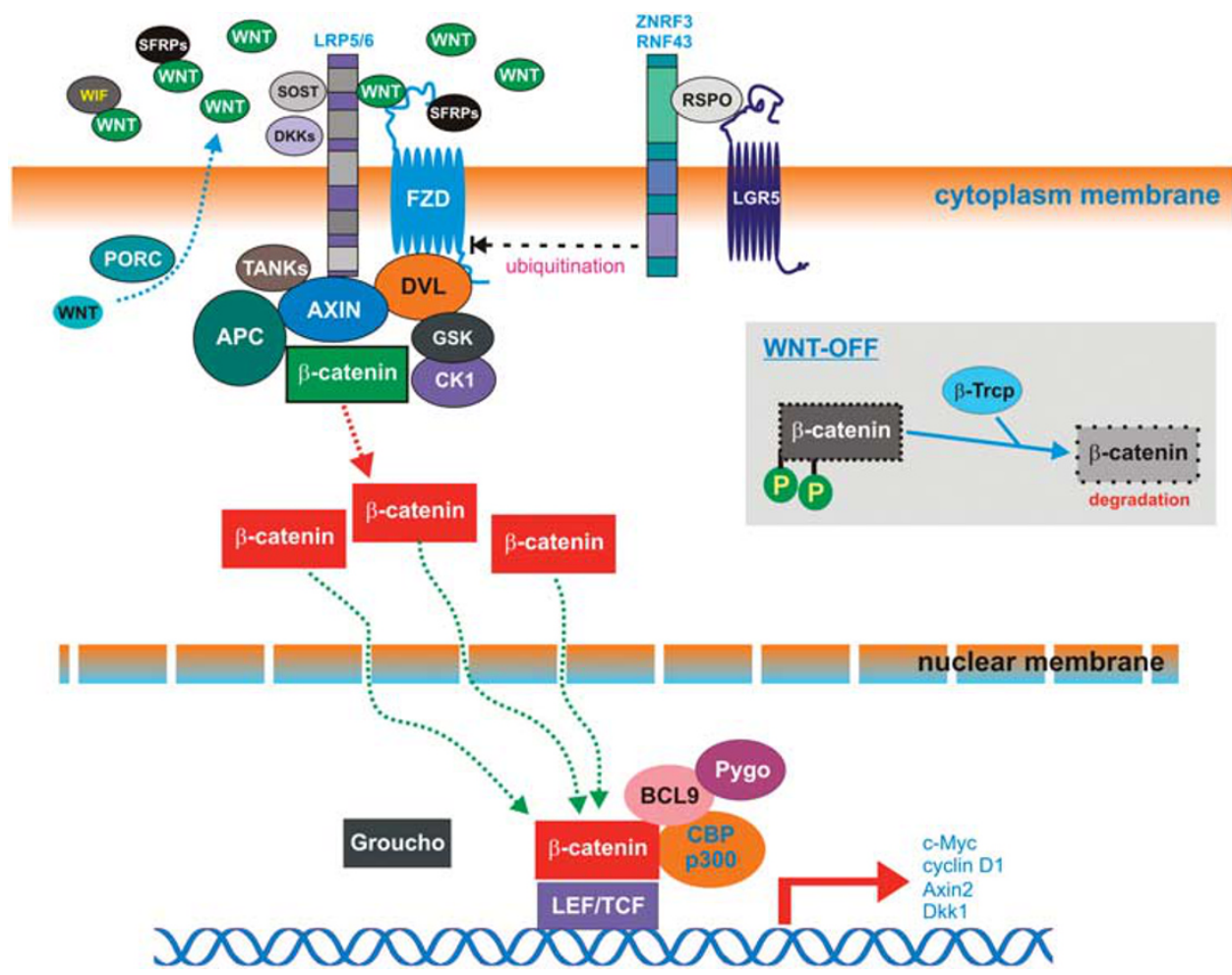

Figure 1 Schematic depiction of the canonical WNT signaling pathway. WNT ligands are posttranslationally modified in ER with the participation of porcupine (PORC) and secreted into the extracellular space, where WNTs interact with receptors FZDs and co-receptors LRP5/6. Antagonists SFRPs and WIF can bind to WNT ligands, while SFRPs can also interact with FZDs. Antagonists SOST and DKKs bind to LRP5/6 to compete with WNT ligands. WNT binding to the receptors initiates the disassembly of the destruction complex consisting of DVL/AXIN/APC/GSK3 $\beta / C K 1$, resulting in the release of the stabilized $\beta$-catenin to cytoplasm, which is subsequently translocated into cell nucleus and regulates WNT target genes in concert with the co-activators $\mathrm{BCL9}$, Pygo, and CBP/p300. TANKs interact with AXIN and promote its degradation. RSPOs interact with LRG5 and membrane-bound E3 ubiquitin ligases ZNRF3/RNF43 and inhibit the ubiquitination-mediated degradation of FZDs. In WNT-OFF cells (the inserted box), the destruction complex is assembled, and the $\beta$-catenin protein is phosphorylated by CK1 and GSK3 $\beta$, and doomed for proteasome-mediated protein degradation.

pathway. A key step in transcriptional activation is the formation of a complex between $\beta$-catenin and TCF/LEF transcription factors. In the absence of $\beta$-catenin, TCF/LEF factors have no transcriptional activity and are bound by transcription repressors, such as Groucho (Figure 1). To generate a transcriptionally active complex, TCF/LEF and $\beta$-catenin recruit CBP or its homolog $\mathrm{p} 300$, as well as other components of the basal transcription machinery, to initiate transcription. ${ }^{65} \mathrm{CBP}$ and $\mathrm{p} 300$ proteins promote histone acetylation. ${ }^{66}$ The acetylation of $\beta$-catenin by $\mathrm{p} 300$ was shown to regulate $\beta$-catenin-Tcf4 interaction. ${ }^{67,68} \mathrm{~A}$ recent study showed that high glucose can induce $\beta$-catenin acetylation and hence enhance signaling through the cancer-associated $\mathrm{Wnt} / \beta$-catenin pathway. ${ }^{69} \mathrm{BCL} 9$ is involved in the majority of $\beta$-catenin-regulated gene transcription. $\beta$-Catenin can bind to the HD2 domain of BCL9, which served as a specific cofactor for $\beta$-catenin-regulated transcription. ${ }^{70}$ The Drosophila Pygopus (Pygo) protein is shown to promote the binding of $\beta$-catenin to WNT responding element and transcriptional active sites by the combination with BCL9- $\beta$-catenin. ${ }^{71}$ It has recently been shown that $\beta$-catenin can interact with other transcription factors (eg, FOXOs, nuclear receptors, Sox, Smad, Oct4) and has an important role in various cellular processes. ${ }^{62,72,73}$ In fact, it was shown that FoxM1 can physically interact with $\beta$-catenin and promote $\beta$-catenin nuclear localization and WNT target-gene expression. ${ }^{74}$ Therefore, the cell context-specific activities of canonical WNT signaling may be accomplished at least in part by differential recruitments of tissue-specific cofactors to the $\beta$-catenin/TCF/LEF complex to regulate the expression of different genes.

\section{R-Spondins Emerge as WNT Signaling Activators}

The R-Spondin (RSPO) family consists of four members (RSPO1-4), emerging as a group of canonical WNT signaling activators. ${ }^{75,76}$ RSPO proteins contain four major functional domains: two cysteine-rich furin-like (CR) domains, a thrombospondin type 1 (TSP1) domain, and a C-terminal region containing basic amino acids. The CR domains (92-94 aa in length) of RSPO proteins are primarily responsible for activation of $\mathrm{WNT} / \beta$-catenin signaling. ${ }^{77,78}$ Deletion of furin-like motifs within the CR domain of RSPO abolishes 
its ability to activate canonical WNT signaling. RSPO activation of canonical WNT signaling pathway may depend on the phosphorylation of LRP5/6 receptors. ${ }^{79}$ It has been recently shown that Lgr proteins (or Leu-rich repeat-containing $G$ protein-coupled receptor) can bind the furin domains of RSPOs with high affinity to promote $\beta$-catenin signaling. . $^{80,81}$ RSPOs, acting through Lgr receptors, inhibit the transmembrane E3 ubiquitin ligases RNF43/ZNRF3 that ubiquitinate and thus degrade FZD receptors, ${ }^{82,83}$ leading to the stabilization of FZD receptors and subsequent enhancement of WNT signal. It should be pointed out that the RSPO/LGR axis is only found in vertebrate systems. ${ }^{84}$

\section{WNT Signaling is Tightly Controlled by its Naturally Occurring Secreted Antagonists}

All essential pathways in mammalian cells are heavily negatively regulated. The canonical WNT signaling pathway is no exception. Numerous inhibitors of WNT signaling are present outside of the cell and affect ligand-receptor interactions. The prototype antagonists, called secreted Frizzled-related proteins (SFRPs), possess FZD-like CRD that competitively binds to WNT ligands and prevents the interaction between WNTs and FZD receptors. ${ }^{85-87}$ Another structurally unrelated secreted inhibitor called WNT inhibitory protein (WIF) can bind WNTs, thereby blocking the interactions between WNT and WNT receptors. ${ }^{88}$

Secreted inhibitors that target co-receptors LRP5/6 also exist. The Dickkopf (DKK) family of proteins can inhibit $\mathrm{WNT} / \beta$-catenin signaling by competitively binding to the WNT co-receptors LRP5/6. ${ }^{89}$ It was suggested that DKK1 may inhibit WNT signaling via inducing LRP6 internalization or degradation through transmembrane Kremen (Krm) proteins, ${ }^{90}$ which was not, however, supported by recent biochemical and genetic studies. ${ }^{91-93}$ WISE and SOST constitute another family of LRP5/6 ligands/antagonists. ${ }^{94-96}$ SOST can disrupt WNT-induced Fz-LRP6 complex in vitro. ${ }^{96}$ Both DKK1 and SOST are strongly implicated in human diseases. ${ }^{22,97,98}$ It is noteworthy that none of the above naturally occurring secreted inhibitors has been identified in Drosophila.

\section{CROSS-TALK BETWEEN WNT AND OTHER MAJOR SIGNALING PATHWAYS}

Given the wide spectrum of WNT effects on target cells, cross-talks with other signaling pathways have an important role in fine-tuning the modulation of WNT signaling during development and in maintaining tissue homeostasis. Here, we discuss several well-established cross-talks between WNT signaling and other signaling pathways.

\section{Some Growth Factor Signaling Pathways can 'Hijack' $\beta$-Catenin Signaling Activity}

It is conceivable that any cellular signaling that can stabilize the $\beta$-catenin protein should be able to activate the downstream events regulated by the $\beta$-catenin-TCF/LEF transcriptional complex. As the essential mediator of the canonical WNT pathway, $\beta$-catenin is aberrantly activated in a multitude of human cancers without any known mutations in the upstream components of the pathway or any increase in WNT expression, suggesting that non-WNT factors may be also capable of activating $\beta$-catenin. In fact, several growth factor and developmental signaling pathways, such as hepatocyte growth factor, ${ }^{99-102}$ epidermal growth factor, ${ }^{103-105}$ insulin-like growth factors, ${ }^{106-111}$ vascular endothelial growth factor, ${ }^{112,113}$ and fibroblast growth factors, ${ }^{114-119}$ have been found to cause the accumulation/ stabilization of the $\beta$-catenin protein and/or to activate $\beta$-catenin activity.

For example, it was shown that EGFR activation involves a kinase signaling cascade that leads to the dissociation of $\beta$-catenin from $\alpha$-catenin at the adherens junction and the eventual nuclear translocation of $\beta$-catenin, ${ }^{103}$ although epidermal growth factor-induced activation of $\beta$-catenin may also involve histone deacetylase 6 (ref. 120) or embryonic pyruvate kinase M2 (PKM2). ${ }^{105}$ The hepatocyte growth factor receptor Met is involved in the phosphorylation of $\beta$-catenin at tyrosine residues 654 and 670 with subsequent nuclear translocation of $\beta$-catenin. ${ }^{100} \mathrm{~A}$ significant correlation exists between the expression of c-Met and abnormal $\beta$-catenin expression in invasive breast carcinoma, implicating cross-talk between the two in breast cancer. ${ }^{101}$ IGF1 or insulin treatment increased $\beta$-catenin/TCF-mediated transcription and cytoplasmic stabilization of $\beta$-catenin, ${ }^{107}$ while IGF1 also induced the stabilization of $\beta$-catenin in prostate cancer and early melanoma cells. ${ }^{110,111}$ FGF19 was shown to increase $\beta$-catenin transcriptional activity in colon cancer cells and in transgenic mice, ${ }^{117,118}$ whereas co-activation of the WNT and fibroblast growth factor pathways in colorectal carcinogenesis leads to a more malignant phenotype. ${ }^{115}$ Interestingly, fibroblast growth factors also cooperate with Wnt1 in mouse mammary tumor virus-induced mammary tumorigenesis. ${ }^{114,116,119}$ Nonetheless, molecular mechanisms for these cross-talks have yet to be fully elucidated.

\section{Cross-Talk between the WNT and TGF- $\beta$ /BMP Signaling Pathways}

The TGF- $\beta$ family includes TGF- $\beta$ and the bone morphogenetic proteins (BMPs), which share a canonical signaling cascade involving two types of receptors (type I and II) and a common set of signal transducers known as Smads. ${ }^{121-126}$ Upon TGF- $\beta$ or BMP binding to the type II receptor, the type I receptor is recruited to form a heterodimer complex, leading to the phosphorylation of the C-terminus of receptor-regulated Smads (R-Smads) (Smad 1, 2, 3, 5, and 8 ), which are then able to complex with the common Smad4. The Smads complex then translocates to the nucleus, binds to DNA, and regulates target gene expression. ${ }^{121-126}$

Cross-talk between the WNT and TGF- $\beta /$ BMP pathways is quite complex and occurs at multiple levels. The ligand production for the two pathways is under regulation by each 
other. For example, BMP4 expression in human colon cancer cells is dependent on the expression of oncogenic $\beta$-catenin. ${ }^{127}$ Conversely, BMP2/4 is capable of regulating production of WNT8. ${ }^{128} \mathrm{Smad}$ and $\beta$-catenin/TCF can form a complex that binds to DNA and regulates shared target gene expression during development. ${ }^{129,130}$ WNT3a and BMP4 synergistically induce expression of common target genes, such as Id2, Msx1, and Msx2. ${ }^{60}$ Many genes have been identified that harbor both Smad and TCF/LEF binding sites within their regulatory sequences, including Tbx6, Msx2, Xtwin, Emx2, Slug, and c-Myc. ${ }^{131-136}$ TGF- $\beta$ RII knockout specifically in the stromal cells leads to increased expression of WNT3a and development of prostatic cancer. ${ }^{137,138}$ Furthermore, it has been shown that Smad7 can directly bind to $\beta$-catenin and induce its degradation by the recruitment of Smurf2. ${ }^{139}$ Smad7 was found to physically associate with $\beta$-catenin, leading to an accumulation of $\beta$-catenin in prostate cancer cells. ${ }^{140} \mathrm{Smad} 7$ can also directly bind to AXIN, which induces disassembly of the degradation complex and subsequent stabilization of $\beta$-catenin at the adherens junction. ${ }^{141}$ It has been recently reported that antagonism between WNT and BMP at the cytoplasmic level can be mediated by a direct interaction of DVL and phosphorylated Smad1. ${ }^{142}$ Therefore, the cross-talk between TGF- $\beta$ /BMP and WNT signaling pathways can be either synergistic or antagonistic depending on the cellular context. $^{143}$

\section{Cross-Talk between the WNT and Notch Signaling Pathways}

Notch signaling pathway is a highly conserved mechanism of intercellular communication and essential for development, patterning, and tissue homeostasis. ${ }^{144-146}$ Notch signaling is transduced through direct cell-to-cell contact and requires activation at the cell surface by ligands of the DSL (Delta and Serrate/Jagged) family. The ligand-receptor interaction causes cleavage of the Notch receptor through intramembrane proteolysis and yields the Notch intracellular domain (NICD), which then translocates to the nucleus and activates downstream target genes through the transcription factor $\mathrm{RBPj}$ and co-factors such as Mastermind. ${ }^{145,146}$

Cross-talk between the Notch and WNT pathways has been observed in many developmental and cellular processes, such as somitogenesis, intestinal epithelial cell fate, and hematopoietic stem cell (HSC) maintenance. ${ }^{147-151}$ Notch can repress WNT signaling during development and homeostasis by associating with $\beta$-catenin, ${ }^{152}$ while WNT activation can antagonize Notch signaling through DVL. ${ }^{153}$ Numerous reports have detailed an opposing role for the WNT and Notch pathways in tumorigenesis as the deletion or inhibition of Notch results in basal cell carcinoma. ${ }^{154}$ Activation of the Delta-Notch pathway inhibits the WNT pathway in neuroblastoma cells. ${ }^{155}$ Notch activation in a human tongue cancer cell line suppressed WNT signaling and led to cell cycle arrest and apoptosis. ${ }^{156}$ The physical interaction between $\beta$-catenin and the cytoplasmic tail of membrane-bound Notch resulted in the degradation of $\beta$-catenin protein. ${ }^{49}$

Nonetheless, WNT and Notch pathways seem to work synergistically in intestinal tumorigenesis adenomas as activation of Notch in APC-mutant mice hyperactive for WNT signaling accelerates adenoma development. ${ }^{157}$ WNT and Notch appear to operate synergistically in other cancer types, such as liver cancer, ${ }^{158}$ prostate cancer, ${ }^{159}$ breast cancer, ${ }^{160,161}$ and leukemia. ${ }^{147}$ Furthermore, Notch ligand Jagged 1 can be transcriptionally activated by $\beta$-catenin. ${ }^{162}$ Nonetheless, detailed mechanisms underlying the cross-talk between WNT and Notch pathways remain to be fully elucidated.

\section{Cross-Talk between the WNT and Hedgehog Signaling Pathways}

The Hedgehog pathway is essential for tissue growth, patterning, and morphogenesis. ${ }^{163}$ The three mammalian Hedgehogs (Hh), Sonic, Indian, and Desert hedgehog (Shh, Ihh, and Dhh) are secreted proteins that undergo cleavage and lipid modification to become active signaling molecules. ${ }^{163,164}$ Binding of $\mathrm{Hh}$ ligand to its receptor, Patched, derepresses the transmembrane protein Smoothened (Smo), thereby inducing a signaling cascade that results in the stabilization of Gli transcription factors, ${ }^{165,166}$ which in turn regulate the expression of target genes. ${ }^{163,164,166}$ In basal cell carcinomas, elevated levels of WNT pathway components were detected in response to Hh signaling abnormalities and Gli1 expression, suggesting a requirement for ligand-driven, canonical $\mathrm{WNT} / \beta$-catenin signaling for $\mathrm{Hh}$ pathway-driven tumorigenesis. ${ }^{167,168}$ Elevated Glil expression was shown to lead to the accumulation of nuclear $\beta$-catenin in endometrial cancers. ${ }^{169} \mathrm{WNT} / \beta$-catenin signaling induces the expression of an RNA-binding protein, CRD-BP, leading to the stabilization of Gli1 mRNA and increased Hedgehog signaling and survival of colorectal cancer cells. ${ }^{170}$ Inhibition of Smo rescues the lethality caused by the loss of APC in mice, suggesting $\mathrm{Hh}$ may be activated in parallel with or downstream of WNT signaling. ${ }^{171}$ Conversely, Hh signaling was shown to positively regulate the WNT pathway. ${ }^{172}$ Reduced expression of Smo in APC mice suppressed $\beta$-catenin-dependent transcription in intestinal adenoma cells independently of the canonical Hh pathway. ${ }^{173}$ Activation of the Hh pathway through Smo or Gli2 increases WNT activity in pancreatic adenocarcinoma. ${ }^{174}$ However, it was also reported that Ihh acts as an antagonist of WNT signaling in colonic epithelial cell differentiation. ${ }^{175} \mathrm{WNT}$ and $\mathrm{Hh}$ signaling was also found to be inversely correlated in gastric cancer specimens as overexpression of Glil suppressed WNT signaling in a gastric cancer cell line. ${ }^{176}$ Therefore, the disparate regulations of WNT and Hh signaling pathways may be cell- or tissue-specific or context-dependent and remain to be full understood. 


\section{Cross-Talk between the WNT and Hippo/YAP/TAZ Signaling Pathways}

The Hippo pathway is a potent regulator of cellular proliferation and differentiation, and has emerged as a crucial regulator of tissue development and homeostasis. ${ }^{177-181}$ The Yes-associated protein (YAP)/transcriptional coactivator with a PDZ-binding domain (TAZ) are the prime mediators of the Hippo pathway. ${ }^{179}$ Activation of the Hippo pathway leads to the phosphorylation and cytoplasmic retention of YAP/TAZ. Although the nuclear localization of YAP/TAZ is essential for the transcriptional activities of the Hippo pathway, nonnuclear TAZ appears to be crucial for the regulation of canonical WNT signaling. ${ }^{182}$ The Hippo pathway seems to restrict $\mathrm{WNT} / \beta$-catenin signaling by promoting an interaction between TAZ and DVL. Cytoplasmic YAP may also counterbalance the effect of WNT signaling by limiting DVL activity. ${ }^{183}$ The Hippo and WNT pathways also cooperate in the nucleus, where YAP interacts with $\beta$-catenin and induces the expression of canonical WNT target genes. ${ }^{184}$ It has been reported that YAP and TAZ are integral components of the $\beta$-catenin destruction complex that serves as cytoplasmic sink for YAP/TAZ. ${ }^{185}$ In WNT-ON cells, YAP/TAZ are physically dislodged from the destruction complex, allowing their nuclear accumulation and activation of WNT/YAP/TAZdependent biological effects. ${ }^{185}$ In WNT-OFF cells, YAP/TAZ are essential for $\beta$-TrCP recruitment to the complex and $\beta$-catenin inactivation. ${ }^{185}$ However, a recent study indicates that APC can regulate Hippo-YAP signaling in a $\beta$-catenin destruction complex-independent manner during intestinal tumorigenesis. ${ }^{186}$ In fact, the activation of YAP is a general hallmark of tubular adenomas from FAP patients; and APC was shown to function as a scaffold protein that facilitates the Hippo kinase cascade by interacting with Sav1 and Lats $1 .{ }^{186}$ More surprisingly, a recent study suggest that YAP/TAZ may function as bona fide downstream effectors of the alternative WNT-YAP/TAZ signaling pathway as WNT5a/b and WNT3a were shown to induce YAP/TAZ activation independent of canonical WNT/ $\beta$-catenin signaling. ${ }^{187}$ The so-called 'alternative WNT-YAP/TAZ signaling axis' consists of WNT-FZD/ ROR-G $\alpha 12 / 13$-Rho GTPases-Lats1/2 and outcomes include YAP/TAZ activation and TEAD-mediated transcription, leading to the fulfillment of YAP/TAZ-mediated biological functions of alternative WNT signaling, such as gene expression, osteogenic differentiation, cell migration, and antagonism of $\mathrm{WNT} / \beta$-catenin signaling. ${ }^{187}$ Although these findings define a $G$ protein-mediated pathway for WNT signaling to YAP/TAZ, it remains to be fully understood to what extent such an alternative pathway transduces either canonical and/or non-canonical WNT signaling.

\section{WNT/ $\beta$-CATENIN SIGNALING AND STEM CELLS SELF-RENEWAL}

Emerging evidence has established the important and wide-range roles of canonical WNT signing in stem cell self-renewal and/or lineage-specific differentiation in diverse tissues and cell types in vivo. ${ }^{27}$ Given the short-range feature of the signaling gradient, WNT signals can function as ideal stem cell niche factors, which may control the immediately adjacent stem cell, leading to the parsimonious control of progenitor cell fate. ${ }^{27,188}$ Here, we discuss the roles of canonical WNT signaling in regulating several well-characterized stem cell systems.

\section{WNT/ $\beta$-Catenin Signaling in Embryonic and Pluripotent Stem Cells}

Embryonic stem cells (ESCs) are generated from the inner cell mass of the blastocyst, and possess the pluripotent capacity to retain their ability to make all cell types within the organism. ${ }^{189} \mathrm{WNT} / \beta$-catenin pathway is required for the establishment and self-renewal of ESCs cells. ${ }^{27,188,190}$ WNT3a or inhibitor of GSK3 $\beta$ was shown to promote the formation of ESC-like colonies. ${ }^{191} \mathrm{WNT} / \beta$-catenin signaling stimulates self-renewal by inhibiting the repressor activity of endogenously expressed TCF3, while $\mathrm{WNT} / \beta$-catenin activation may also result in differentiation. ${ }^{27,188}$ The effects of APC mutation or endogenous GSK $3 \beta$ preventing the activation of $\mathrm{WNT} / \beta$-catenin signaling result in inability to differentiate normally in either embryoid body or teratoma differentiation assays. ${ }^{192} \mathrm{WNT} / \beta$-catenin activation and GSK3 $\beta$ inhibitors can enhance somatic cell reprogramming and iPSC formation. ${ }^{193}$ The efficiency of $\mathrm{WNT} / \beta$-catenin-stimulated reprogramming appears to be stage-dependent; and TCF3/4 and LEF1/TCF1 act temporally in this process. Pluripotency can be maintained as long as the conditions favor the expression of the core transcription factors Oct4, Sox2, and Nanog. $\beta$-Catenin was shown to interact with reprogramming factors Klf4, Oct4, and Sox2, further enhancing the expression of pluripotency related genes. ${ }^{27,188,194}$

\section{WNT/ $\boldsymbol{\beta}$-Catenin Signaling in Mesenchymal Stem Cells}

Mesenchymal stromal cells (MSCs) derived from stroma of bone marrow, adipose tissue, or placental tissue have the potential to differentiate into multiple cell types. ${ }^{22,124,125,195}$ Canonical WNT signaling has a critical role in regulating cell fate decisions of MSCs. The activation of canonical WNT pathway can promote the osteogenic differentiation of MSCs by upregulating the expression of Cbfa1/Runx2 and alkaline phosphatase. ${ }^{98,196}$ Canonical WNT/ $\beta$-catenin signaling was shown to induce overlapping target genes and to act synergistically with osteogenic BMPs in inducing the osteogenic differentiation of MSCs. ${ }^{197-201}$ The adipogenic differentiation is enhanced in the absence of WNT signaling as activation of $\beta$-catenin via ectopic expression of WNT1 was shown to directly suppress PPAR $\gamma$ expression and prevent 3T3-L1 adipogenic differentiation. ${ }^{202}$ GSK3 $\beta$ mediates WNT inhibition of adipogenesis interfering with PPAR $\gamma$ transcriptional activation. ${ }^{203}$ In the cardiac differentiation process of MSCs, the $\mathrm{WNT} / \beta$-catenin signaling pathway had been inhibited. ${ }^{204}$ Blocking the WNT/ $\beta$-catenin signaling can enhance MSC-based granulation tissue formation and myocardial repair. ${ }^{205}$ 
Canonical WNT signals distinctively regulate MSCs in a biphasic manner depending on signal intensity. The proliferation and self-renewal of MSCs were promoted only under low levels of $\mathrm{WNT} / \beta$-catenin, whereas osteogenic differentiation was promoted under high levels of WNT signaling. ${ }^{206}$

\section{WNT/ $\boldsymbol{\beta}$-Catenin Signaling in Intestinal Stem Cells}

Intestinal stem cells have been demonstrated to be divided into two populations: those located at the base of the crypt and those at the position 4 from the base of the crypt. ${ }^{27,207}$ The position 4 cells characterized by the stem cell marker Bmil are thought to be quiescent, slow cycling, and apparently activated only during injury. ${ }^{207-209}$ The crypt base columnar cells residing at the base of the crypt are rapid cycling and responsible for sustained tissue homeostasis, which can be identified by the expression of Lgr5. ${ }^{209,210}$ $\mathrm{WNT} / \beta$-catenin signaling is required for proper stem cell maintenance and differentiation in the intestine. ${ }^{210}$ The expressions of several WNT ligands and receptors (WNT3, 6, 9b, FZD 4, 6, 7, LRP5, SFRP5) are detected in epithelial cells of the intestinal crypt. ${ }^{211}$ WNT antagonist SFRP5 highly expressing in +4 cell surrounding area has been associated with the regulation of the stem cell niche in the intestine. ${ }^{212}$ Numerous target genes of the $\mathrm{WNT} / \beta$-catenin pathway have been identified in the intestine. Sox 9 as both a transcriptional target and a regulator of the WNT pathway has been shown to be required for paneth cell differentiation. ${ }^{213}$ The transcription factor achaete scute-like $2(\mathrm{Ascl} 2)$ acts as an RSPO/ WNT-responsive gene and regulates the expression of the genes essential to the stem cell state together with $\beta$-catenin/ TCF. ${ }^{214}$ EphB2/3 is required for the correct positioning of cells in the intestinal epithelium controlled by $\beta$-catenin and TCF. ${ }^{215}$ Notch and WNT signaling are required both for stem cell maintenance and for a proper balance of differentiation between secretory and absorptive cell lineages. ${ }^{207}$ In the absence of Notch signaling, stem cells preferentially generate secretory cells at the expense of absorptive cells as blocking Notch signaling disturbs the normal function of the intestine stem cells and lead to the mis-expression of prosecretory genes by inhibiting the WNT signaling pathway. ${ }^{207,216}$

\section{WNT/ $\beta$-Catenin Signaling in HSCs}

WNT signaling pathway has a key role in the early stage of hematopoiesis. ${ }^{23,188} \mathrm{WNT} / \beta$-catenin signaling is indispensable in the formation of vascular endothelial cells to HSC transformation process on early stage of hematopoiesis. ${ }^{21,27}$ The WNT signaling is activated in the early stage of embryonic formation of red blood cells. Activation of the $\mathrm{WNT} / \beta$-catenin pathway can increase the specific markers of pronormoblast and induce the formation of hematopoietic progenitors (MPP). ${ }^{217}$ Knockout of WNT3a in mouse decreased the hematopoietic stem/progenitor cells in the fetal liver. $^{218}$ Overexpression of activated N-terminal truncation $\beta$-catenin promoted the expansion of HSC. ${ }^{219} \mathrm{WNT} /$ $\beta$-catenin inhibitors, DKK1 and Wif1, can disrupt the quiescent state of HSCs and result in the loss of HSC self-renewal and decrease hematopoietic reconstitution. ${ }^{220,221}$ Survivin expression, which is regulated by WNT/CBP/ $\beta$-catenin, is important during hematopoiesis and is prominently upregulated in CD34+ hematopoietic stem/progenitor cells upon growth factor treatment, as survivin-deficient hematopoietic progenitors were shown to have defects in erythroid and megakaryocytic lineage formation. ${ }^{222,223}$ $\mathrm{WNT} / \beta$-catenin signaling, together with other pathways, such as Notch, PGE2, and BMPs, is important for maintaining the hematopoietic lineage balance. It was shown in zebrafish that the timed WNT to Notch relay signaling serves as an early upstream mechanism in HSC specification. ${ }^{224,225}$ After the formation of mesoderm, the BMP signaling activates WNT signaling pathway and $\mathrm{Cdx}-\mathrm{Hox}$ to promote hematopoiesis. ${ }^{224,225}$ The BMP and WNT signaling pathways were shown to regulate hematopoiesis related genes and erythroid differentiation through the transcription factors Smad1 and TCF after acute injury of hematopoietic system. ${ }^{226}$

\section{WNT/ $\beta$-Catenin Signaling in Hair Follicle Stem Cells}

Hair follicle (HF) stem cells residing in the HF are quiescent when the follicle is resting, but rapidly expand and differentiate response to hair periodical regeneration, maintenance of adult skin homeostasis, and wound repair. ${ }^{227,228} \mathrm{WNT} / \beta$-catenin signaling is required for embryonic HF morphogenesis. ${ }^{228}$ Forced activated $\beta$-catenin signaling converts embryonic ectoderm to HF fate. The expression of nuclear $\beta$-catenin is described in hair germ progenitor cells at anagen onset, in HF precursor cells during anagen, but undetectable in telogen HFs. ${ }^{229}$ Conditional loss of $\beta$-catenin in skin epithelia leads to HF stem cell depletion, whereas HF stem cell-specific ablation inhibits the proliferation of hair germ progenitor cells and fate specification of bulge stem cells. ${ }^{230}$ TCF3 and TCF4 are present in quiescent stem cells, where $\mathrm{WNT} / \beta$-catenin activity is silent. ${ }^{231}$ Elevation of $\mathrm{WNT} / \beta$-catenin depresses TCF3/TCF4/TLE-bound target genes, including chromatinrepressed genes, and then activates LEF1 to drive the progenitor cells along the hair differentiation lineage. ${ }^{232}$ Pygo2 was shown to function as an important regulator of $\mathrm{WNT} / \beta$-catenin function in skin epithelia and $\beta$-catenin-induced activation of $\mathrm{HF}$ stem/early progenitor cells. $^{233}$ Furthermore, it is well established that canonical WNT signaling regulates the fate of HF stem cells in concert with other signaling pathways in their niches. Notch ligand Jagged- 1 was shown to be a $\mathrm{WNT} / \beta$-catenin target gene in $\mathrm{HF}$ formation of the adult epidermis. ${ }^{162}$ The antagonistic competition between BMP and WNT signaling balances HF stem cell activity, as reduced BMP signaling and increased WNT signaling activated HF stem cell toward hair fate and HF cycle. ${ }^{234}$ WNT7b as a putative target of canonical BMP signaling serves as a key component required for normal $\mathrm{HF}$ stem cells activation during the telogen-anagen transition. ${ }^{235}$ 


\section{WNT/ $\beta$-CATENIN SIGNALING AND TUMORIGENESIS}

Given the important roles and pleiotropic effects of canonical WNT signaling in virtually every organ system in normal tissue homeostasis and tissue injury repair, it is expected that dysregulation of this signaling pathway would be associated with a large array of human diseases, including neurological diseases, inflammatory and fibrotic disease, and disorders of endocrine function and bone metabolism in adults. ${ }^{22,23,27,98}$ Here, we focus on the consequences of aberrant regulations of $\mathrm{WNT} / \beta$-catenin signaling in the development of human cancers.

\section{Aberrant Activation of WNT/ $\beta$-Catenin and Tumorigenesis}

WNT1 was initially discovered as a potential oncogene in mouse mammary glands, which was further substantiated by the fact that WNT1 transgenic mice developed mammary tumors. ${ }^{1,236}$ These early studies strongly suggest a causative role for WNT1 in mammary tumorigenesis. Later studies demonstrated a pivotal relation between hyperactivated $\mathrm{WNT} / \beta$-catenin signaling pathway and the initiation of colorectal cancer. ${ }^{237,238}$ The high frequency of mutations in various components of WNT pathway in many types of human cancers further highlights the importance of activation of WNT/ $\beta$-catenin signaling in tumorigenesis. ${ }^{239,240}$ Germline inactivating mutations in $A P C$, resulting in nuclear accumulation of $\beta$-catenin stability, are found in patients with familial adenomatous polyposis (FAP), ${ }^{13,241}$ while a nonsense mutation in the coding region of the APC gene causes multiple intestinal neoplasia (Min) phenotype in mice. ${ }^{242}$

Dysregulation of the $\mathrm{WNT} / \beta$-catenin pathway has also been widely found in non-colorectal cancers. ${ }^{18}$ For example, it was reported that up to $44 \%$ and $25 \%$ of hepatocellular carcinoma tumors contain mutations of $\beta$-catenin in exon 3 or mutations in AXIN1, respectively. ${ }^{243,244}$ Oncogenic mutations of $\beta$-catenin are commonly found in human skin cancers, including melanoma. ${ }^{245}$ Increasing evidence indicates that $\mathrm{WNT} / \beta$-catenin signaling is involved in pancreatic ductal adenocarcinoma tumorigenesis. ${ }^{174,246,247}$ The results of pancreatic circulating tumor cell RNA studies implicated that WNT2 expression was upregulated, suggesting that WNT2 may be associated with pancreatic ductal adenocarcinoma metastasis. $^{248}$ It is noteworthy that many types of human cancers exhibit nuclear and/or cytoplasmic $\beta$-catenin accumulation, indicating the activation of the canonical WNT pathway without any identifiable mutations in APC, AXINs, $\beta$-catenin, or other components of the canonical WNT pathway. ${ }^{245,249}$ Furthermore, as one of the hallmarks of tumorigenesis telomerase is regulated by $\beta$-catenin. ${ }^{250}$ Conversely, WIF1, a component of the WNT pathway and a competitive inhibitor of WNT pathway, was downregulated in prostate, breast, lung, bladder cancer, and osteosarcoma. ${ }^{251,252}$

Dysregulation of WNT secretion may also have an important role in tumorigenesis. It was reported that
WLS/GPR177 was overexpressed in astrocytic gliomas, and its depletion in glioma and glioma-derived stem-like cells led to decreased cell proliferation and apoptosis. ${ }^{253}$ The loss of Gpr177 interferes with mammary stem cells, leading to deficiencies in cell proliferation and differentiation, and the Gpr177-deficient mice were resistant to malignant transformation. ${ }^{254}$ Interestingly, colorectal cancer cells with mutations in APC or $\beta$-catenin still depend on Wnt ligands and their secretion for a sufficient level of $\beta$-catenin signaling mediated by GRP177/WLS. ${ }^{255}$ Focal chromosomal copy number aberrations identified GPR177/WLS as one of the new candidate driver genes in osteosarcoma. ${ }^{256}$ It was also shown that WLS/GPR177 expression correlated with poor prognosis in B-cell precursor acute lymphoblastic leukemia via Wnt signaling. ${ }^{257}$ It has been recently shown that WLS/ GPR177 can prompt breast cancer cell proliferation via Wnt signaling, ${ }^{257}$ and that WLS/GPR177 expression in gastric, ovarian, and breast cancers was closely associated with HER2 overexpression. $^{258}$

Furthermore, as discussed earlier, Yes-associated protein 1 (YAP1) was shown to be essential to the survival and transformation of $\beta$-catenin-active cancer cell lines, and YAP is induced by $\beta$-catenin in colorectal cancer cells and is upregulated in APC-mutant colorectal cancer cells. ${ }^{259,260}$ The role of YAP and TAZ as mediators of WNT signaling is further supported by the findings from an animal model, which showed that both YAP and TAZ were required for the loss of APC-induced crypt hyperplasia. ${ }^{185}$ Nonetheless, a recent study revealed that YAP is required for the development of APC-deficient adenomas, but APC functions as a scaffold protein to facilitate the Hippo kinase cascade by interacting with Sav1 and Lats1, which is independent from its involvement in the $\beta$-catenin destruction complex. ${ }^{186}$ These findings indicate that although the causative role of aberrantly activated $\mathrm{WNT} / \beta$-catenin signaling in human cancer development is well established, the detailed molecular mechanisms underlying $\mathrm{WNT} / \beta$-catenin signaling in tumorigenesis are far from being clearly understood.

\section{WNT/ $\boldsymbol{\beta}$-Catenin Signaling and Cancer Metastasis}

Cancer metastasis is a complex multistep process involving breaking through the extracellular matrix and basement membrane at the primary tumor sites. ${ }^{261,262} \mathrm{WNT} / \beta$-catenin pathway-related gene and target gene is associated with tumor invasion and metastasis, such as matrix metalloproteinase (MMP) 7, CD44, vascular endothelial growth factor, and E-cadherin. ${ }^{263,264}$ E-cadherin/ $\beta$-catenin complex-mediated cell adhesion is to establish and maintain normal polarity and cell tight junction of epithelial cells. ${ }^{263}$ Epithelial to mesenchymal transition are known about the epithelial plasticity that are important in cancer metastasis. ${ }^{265-267}$ Activation of $\mathrm{WNT} / \beta$-catenin signaling leads to the nuclear translocation of $\beta$-catenin to disturb the E-cadherin $/ \beta$-catenin complex, contributing to the epithelial to mesenchymal transition process and cancer metastasis. ${ }^{265-267}$ 
$\mathrm{WNT} / \beta$-catenin activity usually upregulates the expression of epithelial to mesenchymal transition-promoting genes, including SNAI1/Snail 1, SNAI2/Snail 2 (also known as Slug), ZEB1, ZEB2, E47, and KLF8. 266,267 Activation of the canonical WNT/TCF pathway through LEF1 and HOXB9 was also identified as a determinant of metastasis to brain and bone during lung adenocarcinoma progression. ${ }^{268}$ Furthermore, the $\mathrm{WNT} / \beta$-catenin signaling can upregulate the expression of cyclooxygenase-2 (Cox2) to promote tumor angiogenesis, which subsequently promotes tumor metastasis. It was also reported that the metastasis-stroma interaction in human breast cancer metastasis was regulated by the hepatocyte growth factor/nuclear Met/phospohho-c-Src/ $\beta$-catenin-TCF/WNT pathway. ${ }^{269}$

\section{WNT/ $\beta$-Catenin Signaling and Cancer Stem Cells}

The WNT/ $\beta$-catenin pathway is also involved in the regulation of cancer stem cells (CSCs) from many tissue types. ${ }^{23,188,207,250}$ Many of the CSC surface markers, such as LGR5/GPR49, CD44, CD24, and Epcam, which are used to identify and isolate putative CSC populations in a variety of tissues, are WNT target genes. ${ }^{23,188,207}$ In breast cancer, LGR5-expressing cells exhibit CSC-like properties, including the formation of self-renewing spheres and high tumorigenicity by activating WNT/ $\beta$-catenin signaling. ${ }^{270}$ WNT3a can promote the self-renewal of cancer stem/progenitor cells in acute lymphocytic leukemia and prostate cancer. ${ }^{271,272} \mathrm{CD} 44$ is closely associated with tumor growth, invasion, and metastasis as an important tumor stem cell marker. ${ }^{273}$ In human colon cancer cell line LT97, CD44-positive cells were detected with the expression of nuclear $\beta$-catenin, while CD44-negative cells exhibited no nuclear $\beta$-catenin. ${ }^{274}$ However, it remains to be fully elucidated whether WNT/ $\beta$-catenin signaling regulates normal stem cells/progenitor cells vs CSCs.

\section{TARGETING WNT/ $\beta$-CATENIN SIGNALING FOR CANCER TREATMENT}

The broad involvement and pleiotropism of WNT signaling in stem cells and human diseases has attracted extraordinary amounts of interests in the development of novel strategies targeting this signaling pathway. ${ }^{21,26,275-279}$ One of the earliest such efforts involved the reintroduction of wild-type APC into human colorectal cancer cell lines, which induced growth inhibition and apoptosis of the cancer cells. ${ }^{280}$ Similarly, the expression of AXIN I also promoted apoptosis in cancer cell lines containing mutations in either $\beta$-catenin, APC, or AXIN I. ${ }^{244}$ These experiments strongly suggest that therapeutic intervention targeting WNT signaling can be developed for anticancer therapies.

For the past decade, significant progresses have been made in identifying the druggable targets of the WNT pathway and/or in developing novel small molecules that specifically target WNT/ $\beta$-catenin signaling. ${ }^{26,276-279}$ Although most of these drugs have not yet progressed to evaluation in clinical trials (Table 1), current genomics and proteomics studies enable more targeted approaches for high-throughput screening of the WNT/ $\beta$-catenin pathway, which is expected to deliver clinical drugs in the coming decade. Here, we primarily focus on the recent development of potential anticancer therapies by targeting the WNT signaling pathway. As the WNT pathway lends itself ample targeting nodal points for drug development, numerous efforts have been devoted to targeting WNT signaling at different regulatory levels of the signaling cascade.

\section{Targeting WNT Signaling at Extracellular Level}

Directly targeting WNT ligands may prove to be an attractive strategy for targeting WNT signaling preferentially in cancer cells that exhibit aberrantly overexpressed WNTs. Several WNT-blocking antibodies were developed and shown to inhibit proliferation and induce apoptosis in different cancers. ${ }^{21,281-284}$ Intraperitoneal injections of WNT3A-neutralizing antibodies decrease proliferation and induce apoptosis in a mouse model of prostate cancer. ${ }^{138}$

FZD receptors are another class of logic targets for developing WNT-targeting biologics. One such agent, OMP18R5, was developed by OncoMed Pharmaceuticals and is a humanized monoclonal antibody that binds to FZD1, FZD2, FZD5, FZD7, and FZD8. ${ }^{26}$ OMP18R5 recently completed the Phase Ia clinical trial in patients with advanced solid tumors. ${ }^{26} \mathrm{~A}$ total of 18 patients were treated and, the most common drug-related adverse events included fatigue, vomiting, abdominal pain, constipation, diarrhea, and nausea. There were three cases of prolonged stable disease in patients with neuroendocrine tumors. ${ }^{26}$

The naturally occurring FZD receptor antagonists, SFRPs, are logic agents to target WNT signaling. These factors are extracellular inhibitors that bind directly to WNT ligands or to Frizzled receptors. The SFRP1 or SFRP1-derived peptides were shown to delay HCT116 xenograft tumor formation in nude mice and reduced the proportion of mitotic. ${ }^{285}$ WIFs are also secreted proteins that competitively displace certain WNT ligands from their receptors. Overexpression of WIF1 was shown to inhibit osteosarcoma cell growth in soft agar assays and in xenograft assays. ${ }^{286}$ It is noteworthy that SFRPs may regulate the cell proliferation of some cancer cells, such as prostate cancer cells, in a context-dependent manner, as the overexpression of SFRP4 or SFRP3 decreases the proliferation of human PC3 cells, ${ }^{287}$ whereas the overexpression of SFRP1 promotes the growth of BPH1 prostate cancer cells. ${ }^{288}$ As SFRPs and WIFs are associated with multiple WNTs, it is conceivable that altering SFRP and WIF levels may have pleiotropic effects on cancer cell proliferation.

Alternatively, a competitive inhibition of WNT signaling can be achieved by overexpression of the secreted forms of FZD receptors. In fact, it was reported that administration of a fusion protein consisting of the $\mathrm{Fc}$ region of $\mathrm{IgG}$ fused to the extracellular domain of FZD8 (FZD8CRD) inhibited the formation of tumor xenografts by two non-engineered cancer 
Table 1 Currently known inhibitors of the canonical WNT signaling pathway

\begin{tabular}{|c|c|c|c|c|}
\hline Molecular targets & Inhibitors & Anti-WNT and anticancer activities & $\begin{array}{l}\text { Stage of } \\
\text { development }\end{array}$ & References \\
\hline \multirow[t]{5}{*}{ WNTs } & Antibodies & $\begin{array}{l}\text { WNT-blocking antibodies were developed and } \\
\text { shown to inhibit proliferation and induce apoptosis } \\
\text { in different cancers }\end{array}$ & Preclinical & $21,262-265$ \\
\hline & SFRPS/WIF & $\begin{array}{l}\text { Overexpress naturally occurring antagonists of } \\
\text { WNT ligands }\end{array}$ & & $266-268$ \\
\hline & SFRP peptides & SFRP1 and SFRP1-derived peptides can delay & & 266 \\
\hline & & HCT116 xenograft tumor formation & & \\
\hline & DNA demethylation agents & $\begin{array}{l}\text { Use DNA demethylation agents to reverse } \\
\text { hypermethylation of SFRP promoters }\end{array}$ & & 273 \\
\hline \multirow[t]{2}{*}{ FZDs } & OMP18R5 & $\begin{array}{l}\text { Humanized monoclonal antibody that binds to } \\
\text { FZD1, FZD2, FZD5, FZD7 and FZD8 }\end{array}$ & Phase la & 28 \\
\hline & FZD8CRD & $\begin{array}{l}\text { Fusion protein consisting of the Fc region of } \operatorname{lgG} \\
\text { fused to the extracellular domain of FZD8 }\end{array}$ & Preclinical & $270-271$ \\
\hline \multirow[t]{2}{*}{ DVL } & $\begin{array}{l}\text { NSC668036 } \\
3289-8625 \\
\text { FJ9 }\end{array}$ & $\begin{array}{l}\text { Inhibits the DVL PDZ domain, not reported in cancer } \\
\text { Inhibits the growth of prostate cancer PC-3 cells } \\
\text { Disrupts the interaction between FZD7 and the } \\
\text { PDZ domain of DVL, induces apoptosis and } \\
\text { inhibits H460 lung cancer growth }\end{array}$ & Preclinical & $274-276$ \\
\hline & Sulindac & Inhibits proliferation of lung cancer A549 cells & FDA-approved & 300,301 \\
\hline \multirow[t]{4}{*}{ TANKS } & XAV-939 & $\begin{array}{l}\text { Inhibits colony formation of } \beta \text {-catenin-dependent } \\
\text { DLD-1 cells }\end{array}$ & Preclinical & 277 \\
\hline & JW55 & $\begin{array}{l}\text { Decreases canonical Wnt signaling in SW480 and } \\
\text { HCT-15 colon carcinoma cell lines; reduces cell cycle } \\
\text { progression and proliferation in SW480 cells in vitro }\end{array}$ & & 279 \\
\hline & G007-LK & $\begin{array}{l}\text { Suppresses APC mutation-driven colorectal tumor } \\
\text { growth }\end{array}$ & & 280 \\
\hline & IWR-1 & Inhibits L-cells expressing Wnt3A & & 278 \\
\hline \multirow[t]{2}{*}{ PORC } & $\begin{array}{l}\text { IWP } \\
\text { LGK-974 }\end{array}$ & $\begin{array}{l}\text { Inhibits colorectal cancer cells invasion by WISP2 } \\
\text { Inhibits growth of mouse MMTV-WNT1 tumor } \\
\text { model and human head and neck squamous cell } \\
\text { carcinoma model }\end{array}$ & $\begin{array}{l}\text { Preclinical } \\
\text { Phase I clinical trial }\end{array}$ & $\begin{array}{c}278 \\
259,282\end{array}$ \\
\hline & WNT C59 & $\begin{array}{l}\text { PORC inhibitor with } 10 \text {-fold therapeutic dose over } \\
\text { toxic dose }\end{array}$ & Preclinical & 283 \\
\hline $\begin{array}{l}\text { Activation of CK1a to } \\
\text { promote } \beta \text {-catenin } \\
\text { degradation }\end{array}$ & Pyrvinium & $\begin{array}{l}\text { Pyrvinium synergizes with 5-fluorouracil in mediating } \\
\text { the apoptosis of SW620 colorectal cancer cells and } \\
\text { inhibits the proliferation of SW480 and HCT116 cells. }\end{array}$ & Preclinical & 317 \\
\hline \multirow[t]{5}{*}{$\beta$-Catenin/TCF interaction } & $\begin{array}{l}\text { iCRT3, iCRT5, and iCRT14 } \\
\text { PKF115-584, CGP049090 } \\
\text { and PKF118-310 }\end{array}$ & $\begin{array}{l}\text { Reduced the growth of colorectal cancer cells } \\
\text { Inhibit the growth of HCC cells in xenografts }\end{array}$ & Preclinical & $\begin{array}{c}288 \\
284-286\end{array}$ \\
\hline & 2,4-Diamino-quinazoline & Inhibitor lead of the $\beta$-catenin-TCF4 pathway & & 287 \\
\hline & PNU-74654 & A drug-like $\beta$-catenin-TCF antagonist & & 289 \\
\hline & $\mathrm{BC} 21$ & $\begin{array}{l}\text { An organo-copper complex as the top-ranked compound } \\
\text { that can bind to the armadillo repeat }\end{array}$ & & 290 \\
\hline & AV-65 & Inhibits progression of multiple myeloma in a mouse model & & 291 \\
\hline
\end{tabular}


Table 1 Continued

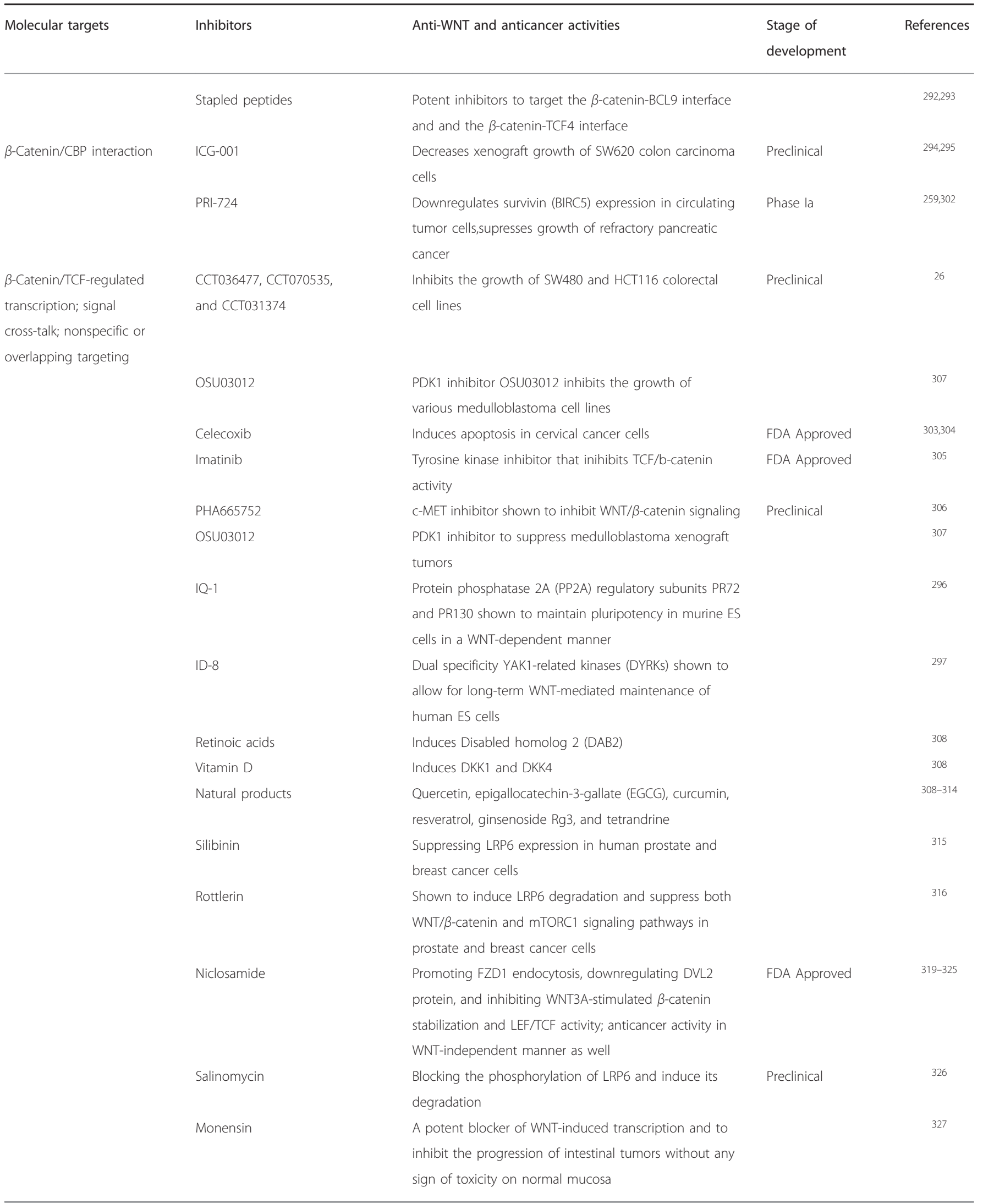


cell lines, the N-TERA2 human testicular cancer line and the PA1 human ovarian cancer cell line. ${ }^{289}$ It was also shown that soluble FZD7 can inhibit WNT signaling and sensitize hepatocellular carcinoma cells towards doxorubicin. ${ }^{290}$ Interestingly, the FZD7 peptides derived from the domains that interact with DVL effectively inhibited the growth of hepatocellular carcinoma cells. ${ }^{291}$

Furthermore, because the SFRP genes are usually silenced by hypermethylation, it is conceivable that drugs that affect the DNA methylation can be used to alter the methylation status of SFRP gene promoters and hence re-activate the expression of SFRPs. It was reported that aberrant epigenetic modification of SFRP gene was one of the major mechanisms by which WNT signaling is activated in human gastric cancer cells, and sodium butyrate can modulate the SFRP1/2 expression through histone modification and promoter demethylation, causing antitumor effects. ${ }^{292}$

\section{Targeting WNT Signaling at Cytoplasmic Membrane Level}

DVL is an essential mediator in the WNT signaling pathway and transduces extracellular WNT signals to downstream components. DVL utilizes its PDZ domain to bind to the carboxyl-terminal region of the FZD receptors. Thus, binders to the PDZ domain of DVL proteins may disrupt the WNT signaling cascade. Three compounds, namely NSC 668036, FJ9, and Compound 3289-8625, were identified through in silico screening and nuclear magnetic resonance spectroscopy approaches, and were shown to block WNT signaling in vivo. ${ }^{293-295}$ The inhibitor NSC668036 provided a basis for rational design of high-affinity inhibitors of the PDZ domain and can block WNT signaling by interrupting the FZD-DVL interaction. ${ }^{293}$ The inhibitor FJ9 can disrupt the interaction between FZD7 and PDZ domain of DVL. ${ }^{294}$ The Compound 3289-8625 was identified as a small molecule inhibitor of PDZ domain of DVL, and was shown to suppress the growth of prostate cancer PC-3 cells. ${ }^{295}$ These results strongly suggest that blocking the PDZ domain of DVL may offer ample opportunities for developing effective and specific inhibitors of the WNT signaling pathway.

\section{Targeting WNT Signaling Intracellular and Nuclear Levels}

\section{Targeting PORC and TANKS}

Recent studies have demonstrated that porcupine (PORC) and tankyrases (TANKs) may serve as promising drug targets of the WNT signaling pathway. PORC is a member of the membrane-bound O-acyltransferase family and adds a palmitoyl group to WNT proteins, which is essential to their signaling ability and is required for WNT secretion. ${ }^{34}$ Tankyrase 1 (TANK1) and tankyrase 2 (TANK2) are members of the larger family of poly(ADP-ribose) polymerase (PARP) enzymes. TANKs interact with a highly conserved domain of AXIN and promote its ubiquitylation and degradation. ${ }^{296}$ Chen et al ${ }^{297}$ identified and characterized two classes of several small molecules called IWRs (inhibitors of WNT response, such as IWR-1) that stabilize the protein AXIN and IWPs (inhibitors of WNT production, such as IWP-2) that inhibit the PORC acyltransferase activity. The IWP inhibitors can efficiently inhibit WNT pathway by disrupting the WNT ligand in colon cancer cell line, while IWR-1 was confirmed as a TANK inhibitor. ${ }^{297}$ Huang et al ${ }^{296}$ also identified another class of TANK inhibitors XAV939, which was shown to induce the stabilization of AXIN. Another tankyrase inhibitor JW55 was shown to decrease canonical Wnt signaling in colon carcinoma cells and to reduce tumor growth in conditional APC-mutant mice. ${ }^{298}$ Similarly, the compound G007-LK displayed favorable pharmacokinetic properties and inhibited in vivo tumor growth in a subset of APC-mutant colorectal cancer xenograft models. $^{299}$ Recent efforts have been devoted to the development of more potent and selective second generation of TANK inhibitors. ${ }^{300}$ Meanwhile, a new PORC inhibitor LGK974 was shown to potently inhibit WNT signaling and exhibit strong efficacy in rodent tumor models, yet well-tolerated, ${ }^{301}$ which has entered a Phase I trial by Novartis. ${ }^{278}$ Another PORC inhibitor WNT C59 was shown to have 10-fold higher than the therapeutic dose to cause extensive loss of intestinal proliferation. ${ }^{302}$

\section{Targeting $\beta$-catenin/TCF transcription complex}

Effectively disrupting the protein-protein interaction between $\mathrm{TCF} / \mathrm{LEF}$ and $\beta$-catenin via small molecules is attractive but technically challenging. Nonetheless, an early high-throughput ELISA-based screening assay of approximately 7000 natural products and 45000 synthetic compounds, which was confirmed by the bioassay for axis duplication in Xenopus laevis embryos, identified two structurally related compounds, PKF115-584 and CGP049090. ${ }^{303}$ Interestingly, both PKF115-584 and CGP049090 were shown to disrupt the $\beta$-catenin-APC interaction as well. ${ }^{303}$ Although these compounds have not advanced to clinical trials, they indeed show anti-WNT efficacy in preclinical models of hepatocellular cancers $^{304}$ and hematologic cancers. ${ }^{305}$ Another high-throughput screen of a large compound library, 2,4-diamino-quinazoline, was identified as an inhibitor lead of the $\beta$-catenin-TCF4 pathway. ${ }^{306}$ A cell-based high-throughput screening in D. melanogaster cells with a WNT-responsive luciferase reporter was carried out to screen 14977 compounds and identified three candidates, namely iCRT3, iCRT5, and iCRT14, which were shown to disrupt the $\beta$-catenin-TCF interaction in vitro and to inhibit the expression of WNT target genes with cytotoxicity in colorectal cancer cells. ${ }^{307} \mathrm{~A}$ combination of virtual and biophysical screening identified the synthetic compound PNU-74654 as a drug-like $\beta$-catenin-TCF antagonist. ${ }^{308} \mathrm{~A}$ virtual screen of the 1990 small-molecule diversity set of the US National Cancer Institute identified the organo-copper complex $\mathrm{BC} 21$ as the top-ranked compound that can bind to the armadillo repeat. ${ }^{309}$ AV-65 was identified by screening from a library 
of more than 100000 small-molecule chemical compounds for novel WNT/ $\beta$-catenin signaling inhibitors and was shown to diminish $\beta$-catenin protein levels and TCF transcriptional activity, as well as to prolong the survival of multiple myeloma-bearing mice. ${ }^{310}$ More recently, a stapled peptide approach was used to identify potent inhibitors to target the $\beta$-catenin-BCL9 interface, ${ }^{311}$ and the $\beta$-catenin-TCF4 interface. ${ }^{312}$ Although many of the above inhibitors possess high translational potential, their biological activity profiles and/or mechanisms of action remain to be fully defined.

\section{Targeting $\beta$-catenin/TCF co-activators}

The $\beta$-catenin/TCF complex needs to recruit the transcriptional co-activator CBP or p300 to regulate the expression of downstream target genes. A small molecule ICG-001 was identified to specifically bind to the co-activator CBP, but not p300, with high affinity. ${ }^{313,314}$ Subsequently, several small molecules (IQ-1 and ID-8), which selectively block the p300- $\beta$-catenin interaction, were also identified. ${ }^{315-317}$ The therapeutic potential of ICG-001 was examined in several preclinical tumor models and was shown to safely eliminate drug-resistant tumor-initiating cells. ${ }^{318-320}$ Another specific $\mathrm{CBP} / \beta$-catenin interaction inhibitor PRI-724 was developed by Prism Pharma and partnered with Eisai Pharmaceuticals and entered an open-label Phase Ia safety study in individuals with solid tumors. ${ }^{278,321}$

\section{Targeting WNT Signaling by Nonspecific Inhibitors and Repurposed Drugs}

Given the pleiotropic effects of the canonical WNT signaling pathway, it is conceivable that many anticancer drugs and/or small molecule inhibitors may target WNT signaling as a part of their mode of action. For example, non-steroidal anti-inflammatory drugs and the selective COX2 inhibitor, celecoxib, were shown to inhibit $\beta$-catenin-dependent transcription in colorectal cancer cells. ${ }^{322,323}$ Other molecules, including CCT036477, СCT070535, and CCT031374, also showed their inhibitory abilities in the SW480 and HCT116 colorectal cell lines. ${ }^{26}$ The tyrosine kinase inhibitor imatinib (Gleevec; Novartis) and c-MET inhibitor PHA665752 were shown to inhibit $\mathrm{WNT} / \beta$-catenin signaling. ${ }^{324,325}$ It was shown that inhibitors of phosphatidylinositol 3-kinase $(\mathrm{PI} 3 \mathrm{~K}) / \mathrm{AKT}$ signaling can inhibit $\mathrm{WNT} / \beta$-catenin signaling cross-talk as PDK1 inhibitor OSU03012 suppressed the growth of established medulloblastoma xenograft tumors in a dose-dependent manner and augmented the antitumor effects of mammalian target of rapamycin (mTOR) inhibitor CCI-779. ${ }^{326}$ Inhibitor IQ-1 of the protein phosphatase 2A (PP2A) regulatory subunits PR72 and PR130 was shown to maintain pluripotency in murine ESCs in a WNT-dependent manner, ${ }^{315}$ whereas the inhibitor ID- 8 of the dual specificity YAK1-related kinases (DYRKs) was shown to allow for long-term WNT-mediated maintenance of human ESCs. ${ }^{316}$ It has been reported that nuclear receptor ligands retinoic acids may induce Disabled homolog 2 (DAB2), whereas vitamin D may induce DKK1 and DKK4. ${ }^{327}$

Derivatives for some natural products, such as quercetin, epigallocatechin-3-gallate (EGCG), curcumin, resveratrol, ginsenoside $\operatorname{Rg} 3$, and tetrandrine, have been reported as potential WNT signaling inhibitors. ${ }^{327-333}$ Silibinin, a natural compound isolated from milk thistle seed extracts, was shown to inhibit $\mathrm{WNT} / \beta$-catenin signaling by suppressing LRP6 expression in human prostate and breast cancer cells. ${ }^{334}$ Another natural plant polyphenol, Rottlerin, was shown to induce LRP6 degradation and suppress both $\mathrm{WNT} / \beta$-catenin and mTORC1 signaling pathways in prostate and breast cancer cells. ${ }^{335}$

Several inhibitors of WNT signaling have been identified by drug-repurposing screening of the libraries of FDA-approved drugs. For example, the anti-helminthic drug pyrvinium was identified as an agent that potentiates $\mathrm{CK} 1 \alpha$ activity and thus promotes the degradation of $\beta$-catenin and the co-activator Pygopus, leading to a reduction in $\mathrm{WNT} / \beta$-catenin signaling. ${ }^{336}$ Another anti-helminthic niclosamide was shown to promote FZD1 endocytosis, downregulate DVL2 protein, and inhibit WNT3A-stimulated $\beta$-catenin stabilization and LEF/TCF activity. ${ }^{337}$ Niclosamide was also shown to suppress cancer cell growth by inducing LRP6 degradation and inhibiting the $\mathrm{WNT} / \beta$-catenin pathway, ${ }^{338}$ and niclosamide can inhibit tumor growth in human colon cancer xenograft model. ${ }^{339}$ More recently, niclosamide was shown to inhibit cell proliferation and/or tumor growth in ovarian cancers, breast cancer, prostate cancer, and osteosarcoma cells, ${ }^{340-344}$ although niclosamide's anticancer activity may be also mediated by inhibiting other signaling pathways. ${ }^{341-344}$ The antibiotic potassium ionophores salinomycin and nigericin were shown to block the phosphorylation of LRP6 and induce its degradation, thereby downregulating WNT signaling. ${ }^{345}$ Interestingly, another polyether ionophore antibiotic, monensin, was shown to be a potent blocker of WNT-induced transcription in the cells stimulated with WNTs or GSK3 inhibitors and to inhibit the progression of intestinal tumors without any sign of toxicity on normal mucosa. ${ }^{346}$ These findings suggest that many small molecule inhibitors may function as WNT signaling modulators.

\section{CONCLUSIONS AND FUTURE DIRECTIONS}

It has been three decades since the ground-breaking discovery of WNT signaling as a fundamental and evolutionarily conserved pathway. For the past decade, there has been a rapid expansion in our understanding about the regulatory circuitry and complexity of this pathway although many details involved in the essential aspects of WNT signaling mechanisms remain to be fully elucidated. Numerous new components of $\mathrm{WNT} / \beta$-catenin signaling, such as RSPOs, LGRs, NZRF3/RNF43, PORC, and TANKS, have been identified and linked to signaling regulation, stem cell functions, and tissue homeostasis. It has been well-established that WNT signaling has important roles in regulating cell self-renewal 
and differentiation in many types of stem cells and CSCs. The lipid-modified WNT signals act primarily over short ranges to control stem cell behavior within the spatial confines of the niche, which implies that in particular tissues, WNT-dependent stem cells are spatially restricted to the vicinity of the WNT-producing niche, physically delimiting the stem cell compartment and preventing uncontrolled stem cell expansion. The short-range action feature of WNT signaling may also account for the context-dependent nature of this pathway as emerging evidence suggests that $\mathrm{WNT} / \beta$-catenin signaling, as well as $\beta$-catenin-independent WNT signaling pathway, can either promote or inhibit cancer progression in a context-dependent manner. Our better understanding of WNT signaling has opened numerous avenues and drawn significant interests for developing novel and effective drugs that may specifically target distinct steps of the WNT signaling pathway although their efficacy and toxicity remain to be fully evaluated.

Nonetheless, the detailed mechanisms underlying WNT signaling under physiological and pathological conditions are far from clearly understood. Future directions should be directed to address the following questions: How is the specificity of individual WNT ligand's interaction with FZDs and co-receptors determined? Through what mechanisms do WNTs interact with co-receptors, such as RORs and RYK? What are the upstream regulatory signals of WNT signaling? How extensively does WNT signaling cross-talk with other major signaling pathways and/or act through what detailed mechanisms? How many downstream target genes are regulated by individual WNTs and/or how these target genes are different in different cell/tissue types? How is canonical or non-canonical WNT signaling determined and at what level(s) of the pathway? How differently do the secreted antagonists interact with individual WNT ligands in determining to transduce canonical or non-canonical signaling? Can components, such as GSK3 $\beta$, of WNT signaling be used or hijacked by other signaling pathways? How is $\beta$-catenin transported into the nucleus? Can we identify any bona fide, safe, and effective WNT inhibitors and eventually move them to treat human diseases? With the rapid technological advances in genomics and systems biology, we expect to get satisfactory answers for many of the above questions in next 5-10 years.

\section{ACKNOWLEDGMENTS}

We apologize to the investigators whose original work was not cited owing to space constraints. The authors' research efforts were supported in part by research grants from the NIH (AT004418, AR50142, and AR054381 to T-CH, $\mathrm{RCH}$, and $\mathrm{HHL}$ ), the 973 Program of Ministry of Science and Technology (MOST) of China (\#2011CB707900 to T-CH), and the National Natural Science Foundation of China (\#81371718, \#81272172, and \#81100309 to KY, GN, and YB), and Chongqing Research Program of Basic Research and Frontier Technology (No. cstc2014jcyjA10010 to HZ). MKM was a recipient of Howard Hughes Medical Institute Medical Research Fellowship.

\section{DISCLOSURE/CONFLICT OF INTEREST}

The authors declare no conflict of interest.
1. Nusse R, Varmus HE. Many tumors induced by the mouse mammary tumor virus contain a provirus integrated in the same region of the host genome. Cell 1982;31:99-109.

2. Nusse R, Varmus $H$. Three decades of Wnts: a personal perspective on how a scientific field developed. Embo J 2012;31:2670-2684.

3. Nusslein-Volhard C, Wieschaus E. Mutations affecting segment number and polarity in Drosophila. Nature 1980;287:795-801.

4. Rijsewijk F, Schuermann M, Wagenaar E et al. The Drosophila homolog of the mouse mammary oncogene int- 1 is identical to the segment polarity gene wingless. Cell 1987;50:649-657.

5. Noordermeer J, Klingensmith J, Perrimon $\mathrm{N}$ et al. Dishevelled and armadillo act in the wingless signalling pathway in Drosophila. Nature 1994;367:80-83.

6. Peifer M, McCrea PD, Green KJ et al. The vertebrate adhesive junction proteins beta-catenin and plakoglobin and the Drosophila segment polarity gene armadillo form a multigene family with similar properties. J Cell Biol 1992;118:681-691.

7. Siegfried $E$, Chou TB, Perrimon N. wingless signaling acts through zeste-white 3, the Drosophila homolog of glycogen synthase kinase3 , to regulate engrailed and establish cell fate. Cell 1992;71: 1167-1179.

8. Siegfried E, Wilder EL, Perrimon N. Components of wingless signalling in Drosophila. Nature 1994;367:76-80.

9. Behrens J, von Kries JP, Kuhl $M$ et al. Functional interaction of beta-catenin with the transcription factor LEF-1. Nature 1996;382: 638-642.

10. Molenaar $M$, van de Wetering $M$, Oosterwegel $M$ et al. XTcf-3 transcription factor mediates beta-catenin-induced axis formation in Xenopus embryos. Cell 1996;86:391-399.

11. Bhanot $P$, Brink $M$, Samos $\mathrm{CH}$ et al. A new member of the frizzled family from Drosophila functions as a Wingless receptor. Nature 1996;382:225-230.

12. Wehrli M, Dougan ST, Caldwell $\mathrm{K}$ et al. Arrow encodes an LDLreceptor-related protein essential for Wingless signalling. Nature 2000;407:527-530.

13. Kinzler KW, Nilbert MC, Su LK et al. Identification of FAP locus genes from chromosome 5q21. Science 1991;253:661-665.

14. Nishisho I, Nakamura Y, Miyoshi $Y$ et al. Mutations of chromosome 5 q21 genes in FAP and colorectal cancer patients. Science 1991;253: 665-669.

15. Rubinfeld B, Souza B, Albert I et al. Association of the APC gene product with beta-catenin. Science 1993;262:1731-1734.

16. Su LK, Vogelstein B, Kinzler KW. Association of the APC tumor suppressor protein with catenins. Science 1993;262:1734-1737.

17. Logan CY, Nusse R. The Wnt signaling pathway in development and disease. Annu Rev Cell Dev Biol 2004;20:781-810.

18. Reya $\mathrm{T}$, Clevers $\mathrm{H}$. Wht signalling in stem cells and cancer. Nature 2005;434:843-850.

19. Klaus A, Birchmeier W. Wnt signalling and its impact on development and cancer. Nat Rev Cancer 2008;8:387-398.

20. MacDonald BT, Tamai K, He X. Wnt/beta-catenin signaling: components, mechanisms, and diseases. Dev Cell 2009;17:9-26.

21. Luo J, Chen J, Deng ZL et al. Wnt signaling and human diseases: what are the therapeutic implications? Lab Invest 2007;87:97-103.

22. Wagner ER, Zhu G, Zhang BQ et al. The therapeutic potential of the Wnt signaling pathway in bone disorders. Curr Mol Pharmacol 2011;4: 14-25.

23. Clevers $H$, Nusse R. Wnt/beta-catenin signaling and disease. Cell 2012;149:1192-1205.

24. Gough NR. Focus issue: Wnt and beta-catenin signaling in development and disease. Sci Signal 2012;5:eg2.

25. Niehrs C. The complex world of WNT receptor signalling. Nat Rev Mol Cell Biol 2012;13:767-779.

26. Anastas JN, Moon RT. WNT signalling pathways as therapeutic targets in cancer. Nat Rev Cancer 2013;13:11-26.

27. Clevers H, Loh KM, Nusse R. Stem cell signaling. An integral program for tissue renewal and regeneration: Wnt signaling and stem cell control. Science 2014;346:1248012.

28. Willert K, Brown JD, Danenberg E et al. Wnt proteins are lipidmodified and can act as stem cell growth factors. Nature 2003;423: 448-452.

29. Janda CY, Waghray D, Levin AM et al. Structural basis of Wnt recognition by Frizzled. Science 2012;337:59-64. 
30. Franch-Marro $X$, Wendler F, Griffith J et al. In vivo role of lipid adducts on Wingless. J Cell Sci 2008;121(Pt 10):1587-1592.

31. Kurayoshi $M$, Yamamoto $H$, Izumi $S$ et al. Post-translational palmitoylation and glycosylation of Wnt-5a are necessary for its signalling. Biochem J 2007;402:515-523.

32. Hofmann K. A superfamily of membrane-bound O-acyltransferases with implications for wnt signaling. Trends Biochem Sci 2000;25: 111-112.

33. Kadowaki T, Wilder E, Klingensmith J et al. The segment polarity gene porcupine encodes a putative multitransmembrane protein involved in Wingless processing. Genes Dev 1996;10:3116-3128.

34. Takada R, Satomi $Y$, Kurata $T$ et al. Monounsaturated fatty acid modification of Wnt protein: its role in Wnt secretion. Dev Cell 2006;11:791-801.

35. Banziger C, Soldini D, Schutt C et al. Wntless, a conserved membrane protein dedicated to the secretion of Wnt proteins from signaling cells. Cell 2006;125:509-522.

36. Fu J, Jiang M, Mirando AJ et al. Reciprocal regulation of Wnt and Gpr177/mouse Wntless is required for embryonic axis formation. Proc Natl Acad Sci USA 2009;106:18598-18603.

37. Port F, Basler K. Wnt trafficking: new insights into Wnt maturation, secretion and spreading. Traffic 2010;11:1265-1271.

38. Yu J, Chia J, Canning CA et al. WLS retrograde transport to the endoplasmic reticulum during Wnt secretion. Dev Cell 2014;29: 277-291.

39. Jiang $\mathrm{M}, \mathrm{Ku}$ WY, Fu J et al. Gpr177 regulates pulmonary vasculature development. Development 2013;140:3589-3594.

40. Yamamoto $\mathrm{H}$, Awada $\mathrm{C}$, Hanaki $\mathrm{H}$ et al. The apical and basolateral secretion of Wnt11 and Wnt3a in polarized epithelial cells is regulated by different mechanisms. J Cell Sci 2013;126(Pt 13):2931-2943.

41. Zhong Z, Zylstra-Diegel CR, Schumacher CA et al. Wntless functions in mature osteoblasts to regulate bone mass. Proc Natl Acad Sci USA 2012;109:E2197-E2204.

42. Zhu $X$, Zhu H, Zhang L et al. Wls-mediated Wnts differentially regulate distal limb patterning and tissue morphogenesis. Dev Biol 2012;365: 328-338.

43. Fu J, Ivy Yu HM, Maruyama T et al. Gpr177/mouse Wntless is essential for Wnt-mediated craniofacial and brain development. Dev Dyn 2011;240:365-371.

44. Galli LM, Szabo LA, Li $L$ et al. Concentration-dependent effects of WNTLESS on WNT1/3A signaling. Dev Dyn 2014;243:1095-1105.

45. Cavallo RA, Cox RT, Moline MM et al. Drosophila Tcf and Groucho interact to repress Wingless signalling activity. Nature 1998;395: 604-608.

46. Roose J, Molenaar M, Peterson J et al. The Xenopus Wnt effector XTcf3 interacts with Groucho-related transcriptional repressors. Nature 1998;395:608-612.

47. Arce L, Pate KT, Waterman ML. Groucho binds two conserved regions of LEF-1 for HDAC-dependent repression. BMC Cancer 2009;9:159.

48. Bilic J, Huang YL, Davidson G et al. Wnt induces LRP6 signalosomes and promotes dishevelled-dependent LRP6 phosphorylation. Science 2007;316:1619-1622.

49. Zeng $X$, Huang $H$, Tamai $K$ et al. Initiation of Wnt signaling: control of Wnt coreceptor Lrp6 phosphorylation/activation via frizzled, dishevelled and axin functions. Development 2008;135:367-375.

50. Metcalfe C, Mendoza-Topaz C, Mieszczanek J et al. Stability elements in the LRP6 cytoplasmic tail confer efficient signalling upon DIX-dependent polymerization. J Cell Sci 2010;123(Pt 9): 1588-1599.

51. Kramps $\mathrm{T}$, Peter $\mathrm{O}$, Brunner $\mathrm{E}$ et al. Wnt/wingless signaling requires $\mathrm{BCL9/legless-mediated} \mathrm{recruitment} \mathrm{of} \mathrm{pygopus} \mathrm{to} \mathrm{the} \mathrm{nuclear} \mathrm{beta-}$ catenin-TCF complex. Cell 2002;109:47-60.

52. Li J, Sutter C, Parker DS et al. CBP/p300 are bimodal regulators of Wnt signaling. EMBO J 2007;26:2284-2294.

53. He TC, Chan TA, Vogelstein B et al. PPARdelta is an APC-regulated target of nonsteroidal anti-inflammatory drugs. Cell 1999;99:335-345.

54. He TC, Sparks AB, Rago $C$ et al. Identification of c-MYC as a target of the APC pathway. Science 1998;281:1509-1512.

55. Tetsu O, McCormick F. Beta-catenin regulates expression of cyclin D1 in colon carcinoma cells. Nature 1999;398:422-426.

56. Shtutman M, Zhurinsky J, Simcha I et al. The cyclin D1 gene is a target of the beta-catenin/LEF-1 pathway. Proc Natl Acad Sci USA 1999;96: $5522-5527$.
57. Yan D, Wiesmann M, Rohan $M$ et al. Elevated expression of axin2 and hnkd mRNA provides evidence that Wnt/beta -catenin signaling is activated in human colon tumors. Proc Natl Acad Sci USA 2001;98: 14973-14978.

58. Lustig B, Jerchow B, Sachs $M$ et al. Negative feedback loop of Wnt signaling through upregulation of conductin/axin2 in colorectal and liver tumors. Mol Cell Biol 2002;22:1184-1193.

59. Jho EH, Zhang $\mathrm{T}$, Domon $\mathrm{C}$ et al. Wnt/beta-catenin/Tcf signaling induces the transcription of Axin2, a negative regulator of the signaling pathway. Mol Cell Biol 2002;22:1172-1183.

60. Willert J, Epping M, Pollack JR et al. A transcriptional response to Wnt protein in human embryonic carcinoma cells. BMC. Dev Biol 2002;2:8.

61. Kikuchi $A$, Yamamoto $H$, Sato $A$ et al. New insights into the mechanism of Wnt signaling pathway activation. Int Rev Cell Mol Biol 2011;291:21-71.

62. Gan XQ, Wang JY, Xi Y et al. Nuclear Dvl, c-Jun, beta-catenin, and TCF form a complex leading to stabilization of beta-catenin-TCF interaction. J Cell Biol 2008;180:1087-1100.

63. Louie SH, Yang XY, Conrad WH et al. Modulation of the beta-catenin signaling pathway by the dishevelled-associated protein Hipk1. PLoS One 2009;4:e4310.

64. Wang W, Li X, Lee M et al. FOXKs promote Wnt/beta-catenin signaling by translocating DVL into the nucleus. Dev Cell 2015;32:707-718.

65. Teo JL, $M a H$, Nguyen $C$ et al. Specific inhibition of $\mathrm{CBP} /$ beta-catenin interaction rescues defects in neuronal differentiation caused by a presenilin-1 mutation. Proc Natl Acad Sci USA 2005;102: 12171-12176.

66. Sasaki T, Hwang $\mathrm{H}$, Nguyen $\mathrm{C}$ et al. The small molecule Wnt signaling modulator ICG-001 improves contractile function in chronically infarcted rat myocardium. PLoS One 2013;8:e75010.

67. Wolf $D$, Rodova M, Miska EA et al. Acetylation of beta-catenin by CREB-binding protein (CBP). J Biol Chem 2002;277:25562-25567.

68. Levy L, Wei Y, Labalette $C$ et al. Acetylation of beta-catenin by p300 regulates beta-catenin-Tcf4 interaction. Mol Cell Biol 2004;24: 3404-3414.

69. Chocarro-Calvo A, Garcia-Martinez JM, Ardila-Gonzalez $\mathrm{S}$ et al. Glucose-induced beta-catenin acetylation enhances Wnt signaling in cancer. Mol Cell 2013:49:474-486.

70. Kessler R, Hausmann G, Basler K. The PHD domain is required to link Drosophila Pygopus to Legless/beta-catenin and not to histone H3. Mech Dev 2009;126:752-759.

71. Miller TC, Rutherford TJ, Johnson CM et al. Allosteric remodelling of the histone $\mathrm{H} 3$ binding pocket in the Pygo2 PHD finger triggered by its binding to the B9L/BCL9 co-factor. J Mol Biol 2010;401: 969-984.

72. van den Bosch $M H$, Blom $A B$, van Lent $\mathrm{PL}$ et al. Canonical Wnt signaling skews TGF-beta signaling in chondrocytes towards signaling via ALK1 and Smad 1/5/8. Cell Signal 2014;26:951-958.

73. Funa NS, Schachter $K A$, Lerdrup $M$ et al. Beta-catenin regulates primitive streak induction through collaborative interactions with SMAD2/SMAD3 and OCT4. Cell Stem Cell 2015;16:639-652.

74. Zhang N, Wei P, Gong A et al. FoxM1 promotes beta-catenin nuclear localization and controls Wnt target-gene expression and glioma tumorigenesis. Cancer Cell 2011;20:427-442.

75. Kim KA, Zhao J, Andarmani S et al. R-Spondin proteins: a novel link to beta-catenin activation. Cell Cycle 2006;5:23-26.

76. Nam JS, Turcotte TJ, Smith PF et al. Mouse cristin/R-spondin family proteins are novel ligands for the Frizzled 8 and LRP6 receptors and activate beta-catenin-dependent gene expression. J Biol Chem 2006:281:13247-13257.

77. Kazanskaya O, Glinka A, del Barco Barrantes I et al. R-Spondin2 is a secreted activator of $\mathrm{Wnt} /$ beta-catenin signaling and is required for Xenopus myogenesis. Dev Cell 2004;7:525-534.

78. Kim KA, Wagle $M$, Tran $K$ et al. R-Spondin family members regulate the Wnt pathway by a common mechanism. Mol Biol Cell 2008;19: 2588-2596.

79. Wei Q, Yokota C, Semenov MV et al. R-spondin 1 is a high affinity ligand for LRP6 and induces LRP6 phosphorylation and beta-catenin signaling. J Biol Chem 2007;282:15903-15911.

80. Carmon KS, Gong X, Lin Q et al. R-spondins function as ligands of the orphan receptors LGR4 and LGR5 to regulate Wnt/beta-catenin signaling. Proc Natl Acad Sci USA 2011;108:11452-11457. 
81. de Lau W, Barker N, Low TY et al. Lgr5 homologues associate with Wnt receptors and mediate R-spondin signalling. Nature 2011;476: 293-297.

82. Hao HX, Xie Y, Zhang $\mathrm{Y}$ et al. ZNRF3 promotes Wnt receptor turnover in an R-spondin-sensitive manner. Nature 2012;485:195-200.

83. Koo BK, Spit M, Jordens I et al. Tumour suppressor RNF43 is a stemcell E3 ligase that induces endocytosis of Wnt receptors. Nature 2012;488:665-669.

84. de Lau WB, Snel B, Clevers HC. The R-spondin protein family. Genome Biol 2012;13:242.

85. Finch PW, He X, Kelley MJ et al. Purification and molecular cloning of a secreted, Frizzled-related antagonist of Wnt action. Proc Natl Acad Sci USA 1997;94:6770-6775.

86. Kawano $Y$, Kypta R. Secreted antagonists of the Wnt signalling pathway. J Cell Sci 2003;116(Pt 13):2627-2634.

87. Ladher RK, Church VL, Allen S et al. Cloning and expression of the Wnt antagonists Sfrp- 2 and Frzb during chick development. Dev Biol 2000;218:183-198.

88. Hsieh JC, Kodjabachian L, Rebbert ML et al. A new secreted protein that binds to Wnt proteins and inhibits their activities. Nature 1999;398:431-436.

89. Glinka A, Wu W, Delius $\mathrm{H}$ et al. Dickkopf-1 is a member of a new family of secreted proteins and functions in head induction. Nature 1998;391:357-362

90. Mao B, Wu W, Davidson G et al. Kremen proteins are Dickkopf receptors that regulate Wnt/beta-catenin signalling. Nature 2002;417:664-667.

91. Ellwanger K, Saito H, Clement-Lacroix $P$ et al. Targeted disruption of the Wnt regulator Kremen induces limb defects and high bone density. Mol Cell Biol 2008;28:4875-4882.

92. Semenov MV, Zhang $X, H e X$. DKK1 antagonizes Wnt signaling without promotion of LRP6 internalization and degradation. J Biol Chem 2008;283:21427-21432.

93. Wang K, Zhang Y, Li X et al. Characterization of the Kremen-binding site on Dkk1 and elucidation of the role of Kremen in Dkk-mediated Wnt antagonism. J Biol Chem 2008;283:23371-23375.

94. Itasaki N, Jones CM, Mercurio S et al. Wise, a context-dependent activator and inhibitor of Wnt signalling. Development 2003;130: 4295-4305.

95. Li X, Zhang $\mathrm{Y}$, Kang $\mathrm{H}$ et al. Sclerostin binds to LRP5/6 and antagonizes canonical Wnt signaling. J Biol Chem 2005;280:19883-19887.

96. Semenov M, Tamai K, He X. SOST is a ligand for LRP5/LRP6 and a Wnt signaling inhibitor. J Biol Chem 2005;280:26770-26775.

97. Johnson ML, Harnish K, Nusse R et al. LRP5 and Wnt signaling: a union made for bone. J Bone Miner Res 2004;19:1749-1757.

98. Kim JH, Liu X, Wang J et al. Wnt signaling in bone formation and its therapeutic potential for bone diseases. Ther Adv Musculoskelet Dis 2013;5:13-31.

99. Apte U, Zeng G, Muller $P$ et al. Activation of Wnt/beta-catenin pathway during hepatocyte growth factor-induced hepatomegaly in mice. Hepatology 2006:44:992-1002.

100. Monga SP, Mars WM, Pediaditakis P et al. Hepatocyte growth factor induces Wnt-independent nuclear translocation of beta-catenin after Met-beta-catenin dissociation in hepatocytes. Cancer Res 2002;62: 2064-2071.

101. Nakopoulou L, Gakiopoulou H, Keramopoulos A et al. c-met tyrosine kinase receptor expression is associated with abnormal beta-catenin expression and favourable prognostic factors in invasive breast carcinoma. Histopathology 2000;36:313-325.

102. Rasola A, Fassetta M, De Bacco F et al. A positive feedback loop between hepatocyte growth factor receptor and beta-catenin sustains colorectal cancer cell invasive growth. Oncogene 2007;26: 1078-1087.

103. Ji H, Wang J, Nika $\mathrm{H}$ et al. EGF-induced ERK activation promotes CK2mediated disassociation of alpha-Catenin from beta-Catenin and transactivation of beta-Catenin. Mol Cell 2009;36:547-559.

104. Ochiai A, Akimoto S, Kanai $Y$ et al. c-erbB-2 gene product associates with catenins in human cancer cells. Biochem Biophys Res Commun 1994;205:73-78.

105. Yang $\mathrm{W}, \mathrm{Xia} \mathrm{Y}$, Ji $\mathrm{H}$ et al. Nuclear PKM2 regulates beta-catenin transactivation upon EGFR activation. Nature 2011;480:118-122.

106. Bommer GT, Feng Y, lura A et al. IRS1 regulation by Wnt/beta-catenin signaling and varied contribution of IRS1 to the neoplastic phenotype. J Biol Chem 2010;285:1928-1938.
107. Desbois-Mouthon C, Cadoret A, Blivet-Van Eggelpoel MJ et al. Insulin and IGF-1 stimulate the beta-catenin pathway through two signalling cascades involving GSK-3beta inhibition and Ras activation. Oncogene 2001;20:252-259.

108. Longato L, de la Monte $\mathrm{S}$, Kuzushita $\mathrm{N}$ et al. Overexpression of insulin receptor substrate- 1 and hepatitis $\mathrm{Bx}$ genes causes premalignant alterations in the liver. Hepatology 2009;49:1935-1943.

109. Ramocki NM, Wilkins HR, Magness ST et al. Insulin receptor substrate1 deficiency promotes apoptosis in the putative intestinal crypt stem cell region, limits Apcmin/+ tumors, and regulates Sox9. Endocrinology 2008;149:261-267.

110. Satyamoorthy K, Li G, Vaidya B et al. Insulin-like growth factor-1 induces survival and growth of biologically early melanoma cells through both the mitogen-activated protein kinase and beta-catenin pathways. Cancer Res 2001;61:7318-7324.

111. Verras M, Sun Z. Beta-catenin is involved in insulin-like growth factor 1-mediated transactivation of the androgen receptor. Mol Endocrinol 2005; 19:391-398.

112. Birdsey GM, Shah AV, Dufton $\mathrm{N}$ et al. The endothelial transcription factor ERG promotes vascular stability and growth through Wnt/betacatenin signaling. Dev Cell 2015;32:82-96.

113. Naik S, Dothager RS, Marasa J et al. Vascular endothelial growth factor receptor-1 is synthetic lethal to aberrant $\{$ beta\}-catenin activation in colon cancer. Clin Cancer Res 2009;15:7529-7537.

114. Clausse N, Baines D, Moore R et al. Activation of both Wnt-1 and Fgf-3 by insertion of mouse mammary tumor virus downstream in the reverse orientation: a reappraisal of the enhancer insertion model. Virology 1993;194:157-165.

115. Katoh M, Katoh M. Cross-talk of WNT and FGF signaling pathways at GSK3beta to regulate beta-catenin and SNAIL signaling cascades. Cancer Biol Ther 2006;5:1059-1064.

116. Lee FS, Lane TF, Kuo A et al. Insertional mutagenesis identifies a member of the Wnt gene family as a candidate oncogene in the mammary epithelium of int-2/Fgf-3 transgenic mice. Proc Natl Acad Sci USA 1995;92:2268-2272.

117. Nicholes K, Guillet S, Tomlinson E et al. A mouse model of hepatocellular carcinoma: ectopic expression of fibroblast growth factor 19 in skeletal muscle of transgenic mice. Am J Pathol 2002;160: 2295-2307.

118. Pai R, Dunlap D, Qing J et al. Inhibition of fibroblast growth factor 19 reduces tumor growth by modulating beta-catenin signaling. Cancer Res 2008;68:5086-5095.

119. Shackleford GM, MacArthur CA, Kwan HC et al. Mouse mammary tumor virus infection accelerates mammary carcinogenesis in Wnt-1 transgenic mice by insertional activation of int-2/Fgf-3 and hst/Fgf- 4 . Proc Natl Acad Sci USA 1993;90:740-744.

120. Li Y, Zhang X, Polakiewicz RD et al. HDAC6 is required for epidermal growth factor-induced beta-catenin nuclear localization. J Biol Chem 2008;283:12686-12690.

121. Chen D, Zhao M, Mundy GR. Bone morphogenetic proteins. Growth Factors 2004;22:233-241.

122. Dumont N, Arteaga CL. Targeting the TGF beta signaling network in human neoplasia. Cancer Cell 2003;3:531-536.

123. Yingling JM, Blanchard KL, Sawyer JS. Development of TGF-beta signalling inhibitors for cancer therapy. Nat Rev Drug Discov 2004;3: 1011-1022.

124. Wang RN, Green J, Wang Z et al. Bone morphogenetic protein (BMP) signaling in development and human diseases. Genes Dis 2014;1: 87-105.

125. Luther G, Wagner ER, Zhu G et al. BMP-9 induced osteogenic differentiation of mesenchymal stem cells: molecular mechanism and therapeutic potential. Curr Gene Ther 2011;11:229-240.

126. Lamplot JD, Qin J, Nan G et al. BMP9 signaling in stem cell differentiation and osteogenesis. Am J Stem Cells 2013;2:1-21.

127. Kim JS, Crooks $H$, Dracheva $T$ et al. Oncogenic beta-catenin is required for bone morphogenetic protein 4 expression in human cancer cells. Cancer Res 2002;62:2744-2748.

128. Hoppler S, Moon RT. BMP-2/-4 and Wnt-8 cooperatively pattern the Xenopus mesoderm. Mech Dev 1998;71:119-129.

129. Labbe $E$, Letamendia A Attisano L. Association of Smads with lymphoid enhancer binding factor $1 / T$ cell-specific factor mediates cooperative signaling by the transforming growth factor-beta and wnt pathways. Proc Natl Acad Sci USA 2000;97:8358-8363. 
130. Nishita $M$, Hashimoto $M K$, Ogata $S$ et al. Interaction between Wnt and TGF-beta signalling pathways during formation of Spemann's organizer. Nature 2000;403:781-785.

131. Szeto DP, Kimelman D. Combinatorial gene regulation by Bmp and Wnt in zebrafish posterior mesoderm formation. Development 2004;131:3751-3760.

132. Hussein SM, Duff EK, Sirard C. Smad4 and beta-catenin co-activators functionally interact with lymphoid-enhancing factor to regulate graded expression of Msx2. J Biol Chem 2003;278:48805-48814.

133. Letamendia A, Labbe $E$, Attisano L. Transcriptional regulation by Smads: cross-talk between the TGF-beta and Wnt pathways. J Bone Joint Surg Am 2001;83-A Suppl 1(Pt 1):S31-S39.

134. Theil T, Aydin S, Koch $\mathrm{S}$ et al. Wnt and Bmp signalling cooperatively regulate graded $E m \times 2$ expression in the dorsal telencephalon. Development 2002;129:3045-3054.

135. Sakai D, Tanaka $Y$, Endo $Y$ et al. Regulation of Slug transcription in embryonic ectoderm by beta-catenin-Lef/Tcf and BMP-Smad signaling. Dev Growth Differ 2005;47:471-482.

136. Hu MC, Rosenblum ND. Smad1, beta-catenin and Tcf4 associate in a molecular complex with the Myc promoter in dysplastic renal tissue and cooperate to control Myc transcription. Development 2005;132: 215-225.

137. Bhowmick NA, Chytil A, Plieth D et al. TGF-beta signaling in fibroblasts modulates the oncogenic potential of adjacent epithelia. Science 2004;303:848-851.

138. Li X, Placencio V, Iturregui JM et al. Prostate tumor progression is mediated by a paracrine TGF-beta/Wnt3a signaling axis. Oncogene 2008;27:7118-7130.

139. Han G, Li AG, Liang $Y Y$ et al. Smad7-induced beta-catenin degradation alters epidermal appendage development. Dev Cell 2006;11:301-312.

140. Edlund S, Lee SY, Grimsby S et al. Interaction between Smad7 and beta-catenin: importance for transforming growth factor betainduced apoptosis. Mol Cell Biol 2005;25:1475-1488.

141. Tang $Y$, Liu $Z$, Zhao $L$ et al. Smad7 stabilizes beta-catenin binding to E-cadherin complex and promotes cell-cell adhesion. J Biol Chem 2008;283:23956-23963.

142. Song J, McColl J, Camp E et al. Smad1 transcription factor integrates BMP2 and Wnt3a signals in migrating cardiac progenitor cells. Proc Natl Acad Sci USA 2014;111:7337-7342.

143. Itasaki N, Hoppler S. Cross-talk between Wnt and bone morphogenic protein signaling: a turbulent relationship. Dev Dyn 2010;239:16-33.

144. Artavanis-Tsakonas S, Rand MD, Lake RJ. Notch signaling: cell fate control and signal integration in development. Science 1999;284: 770-776.

145. Fortini ME. Notch signaling: the core pathway and its posttranslational regulation. Dev Cell 2009;16:633-647.

146. Kopan R, llagan MX. The canonical Notch signaling pathway: unfolding the activation mechanism. Cell 2009;137:216-233.

147. Duncan AW, Rattis FM, DiMascio LN et al. Integration of Notch and Wnt signaling in hematopoietic stem cell maintenance. Nat Immunol 2005;6:314-322.

148. Galceran J, Sustmann C, Hsu SC et al. LEF1-mediated regulation of Delta-like1 links Wnt and Notch signaling in somitogenesis. Genes Dev 2004;18:2718-2723.

149. Nakamura T, Tsuchiya K, Watanabe M. Cross-talk between Wnt and Notch signaling in intestinal epithelial cell fate decision. J Gastroenterol 2007;42:705-710.

150. Collu GM, Hidalgo-Sastre A, Brennan K. Wnt-Notch signalling cross-talk in development and disease. Cell Mol Life Sci 2014;71:3553-3567.

151. Munoz-Descalzo S, de Navascues J, Arias AM. Wnt-Notch signalling: an integrated mechanism regulating transitions between cell states. Bioessays 2012;34:110-118.

152. Hayward P, Brennan K, Sanders P et al. Notch modulates Wnt signalling by associating with Armadillo/beta-catenin and regulating its transcriptional activity. Development 2005;132:1819-1830.

153. Axelrod JD, Matsuno K, Artavanis-Tsakonas S et al. Interaction between Wingless and Notch signaling pathways mediated by dishevelled. Science 1996;271:1826-1832.

154. Nicolas $M$, Wolfer $A$, Raj $K$ et al. Notch1 functions as a tumor suppressor in mouse skin. Nat Genet 2003;33:416-421.

155. Revet I, Huizenga G, Koster J et al. MSX1 induces the Wnt pathway antagonist genes DKK1, DKK2, DKK3, and SFRP1 in neuroblastoma cells, but does not block Wnt3 and Wnt5A signalling to DVL3. Cancer Lett 2010;289:195-207.

156. Duan L, Yao J, Wu X et al. Growth suppression induced by Notch1 activation involves Wnt-beta-catenin down-regulation in human tongue carcinoma cells. Biol Cell 2006;98:479-490.

157. Fre S, Pallavi SK, Huyghe M et al. Notch and Wnt signals cooperatively control cell proliferation and tumorigenesis in the intestine. Proc Natl Acad Sci USA 2009;106:6309-6314.

158. Lopez-Terrada D, Gunaratne PH, Adesina AM et al. Histologic subtypes of hepatoblastoma are characterized by differential canonical Wnt and Notch pathway activation in DLK+ precursors. Hum Pathol 2009;40:783-794.

159. Moreno CS. The Sex-determining region Y-box 4 and homeobox C6 transcriptional networks in prostate cancer progression: cros-stalk with the Wnt, Notch, and PI3K pathways. Am J Pathol 2010;176: 518-527.

160. Collu GM, Brennan K. Cooperation between Wnt and Notch signalling in human breast cancer. Breast Cancer Res 2007;9:105.

161. Ayyanan A, Civenni G, Ciarloni L et al. Increased Wnt signaling triggers oncogenic conversion of human breast epithelial cells by a Notch-dependent mechanism. Proc Natl Acad Sci USA 2006;103: 3799-3804.

162. Estrach S, Ambler CA, Lo Celso $C$ et al. Jagged 1 is a beta-catenin target gene required for ectopic hair follicle formation in adult epidermis. Development 2006;133:4427-4438.

163. Ingham PW, McMahon AP. Hedgehog signaling in animal development: paradigms and principles. Genes Dev 2001;15:3059-3087.

164. van Den Heuvel M. Fat hedgehogs, slower or richer? Sci STKE 2001;2001:pe31.

165. Taipale J, Beachy PA. The Hedgehog and Wnt signalling pathways in cancer. Nature 2001;411:349-354.

166. Hooper JE, Scott MP. Communicating with Hedgehogs. Nat Rev Mol Cell Biol 2005;6:306-317.

167. Bonifas JM, Pennypacker S, Chuang PT et al. Activation of expression of hedgehog target genes in basal cell carcinomas. J Invest Dermatol 2001;116:739-742.

168. Yang SH, Andl T, Grachtchouk V et al. Pathological responses to oncogenic Hedgehog signaling in skin are dependent on canonical Wnt/beta3-catenin signaling. Nat Genet 2008:40:1130-1135.

169. Liao X, Siu MK, Au CW et al. Aberrant activation of hedgehog signaling pathway contributes to endometrial carcinogenesis through beta-catenin. Mod Pathol 2009;22:839-847.

170. Noubissi FK, Goswami S, Sanek NA et al. Wnt signaling stimulates transcriptional outcome of the Hedgehog pathway by stabilizing GLI1 mRNA. Cancer Res 2009;69:8572-8578.

171. Varnat F, Zacchetti G, Ruiz i Altaba A. Hedgehog pathway activity is required for the lethality and intestinal phenotypes of mice with hyperactive Wnt signaling. Mech Dev 2010;127:73-81.

172. Kim BM, Choi MY. New insights into the role of Hedgehog signaling in gastrointestinal development and cancer. Gastroenterology 2009;137:422-424.

173. Arimura S, Matsunaga A, Kitamura $T$ et al. Reduced level of smoothened suppresses intestinal tumorigenesis by downregulation of Wnt signaling. Gastroenterology 2009;137:629-638.

174. Pasca di Magliano M, Biankin AV, Heiser PW et al. Common activation of canonical Wnt signaling in pancreatic adenocarcinoma. PLoS One 2007;2:e1155.

175. van den Brink GR, Bleuming SA, Hardwick JC et al. Indian Hedgehog is an antagonist of Wnt signaling in colonic epithelial cell differentiation. Nat Genet 2004;36:277-282.

176. Yanai K, Nakamura M, Akiyoshi T et al. Cross-talk of hedgehog and Wnt pathways in gastric cancer. Cancer Lett 2008;263:145-156.

177. Dong J, Feldmann G, Huang J et al. Elucidation of a universal sizecontrol mechanism in Drosophila and mammals. Cell 2007;130: $1120-1133$.

178. Varelas X. The Hippo pathway effectors TAZ and YAP in development, homeostasis and disease. Development 2014;141:1614-1626.

179. Hansen CG, Moroishi T, Guan KL. YAP and TAZ: a nexus for Hippo signaling and beyond. Trends Cell Biol 2015;25:499-513.

180. Piccolo S, Dupont S, Cordenonsi M. The biology of YAP/TAZ: hippo signaling and beyond. Physiol Rev 2014;94:1287-1312.

181. Wang Z, Ye J, Deng $Y$ et al. Wnt Hippo: A balanced act or dynamic duo? Genes Dis 2014;1:127-128. 
182. Ramos A, Camargo FD. The Hippo signaling pathway and stem cell biology. Trends Cell Biol 2012;22:339-346.

183. Barry ER, Morikawa T, Butler BL et al. Restriction of intestinal stem cell expansion and the regenerative response by YAP. Nature 2013;493: 106-110.

184. Heallen $T$, Zhang $M$, Wang J et al. Hippo pathway inhibits Wnt signaling to restrain cardiomyocyte proliferation and heart size. Science 2011;332:458-461.

185. Azzolin L, Panciera T, Soligo $S$ et al. YAP/TAZ incorporation in the beta-catenin destruction complex orchestrates the Wnt response. Cell 2014;158:157-170.

186. Cai J, Maitra A, Anders RA et al. beta-Catenin destruction complexindependent regulation of Hippo-YAP signaling by APC in intestinal tumorigenesis. Genes Dev 2015;29:1493-1506.

187. Park HW, Kim YC, Yu B et al. Alternative Wnt signaling activates YAP/ TAZ. Cell 2015;162:780-794.

188. Holland JD, Klaus A, Garratt AN et al. Wnt signaling in stem and cancer stem cells. Curr Opin Cell Biol 2013;25:254-264.

189. Hanna J, Markoulaki S, Mitalipova M et al. Metastable pluripotent states in NOD-mouse-derived ESCs. Cell Stem Cell 2009;4:513-524.

190. Merrill BJ. Wnt pathway regulation of embryonic stem cell selfrenewal. Cold Spring Harb Perspect Biol 2012;4:a007971.

191. Sato N, Meijer L, Skaltsounis L et al. Maintenance of pluripotency in human and mouse embryonic stem cells through activation of Wnt signaling by a pharmacological GSK-3-specific inhibitor. Nat Med 2004;10:55-63.

192. Abu-Remaileh $M$, Gerson A, Farago $M$ et al. Oct-3/4 regulates stem cell identity and cell fate decisions by modulating Wnt/beta-catenin signalling. EMBO J 2010;29:3236-3248.

193. Lluis F, Pedone $\mathrm{E}$, Pepe $\mathrm{S}$ et al. Periodic activation of Wnt/beta-catenin signaling enhances somatic cell reprogramming mediated by cell fusion. Cell Stem Cell 2008;3:493-507.

194. Zhang $\mathrm{P}$, Chang $\mathrm{WH}$, Fong $\mathrm{B}$ et al. Regulation of induced pluripotent stem (iPS) cell induction by Wnt/beta-catenin signaling. J Biol Chem 2014;289:9221-9232.

195. Rastegar F, Shenaq D, Huang J et al. Mesenchymal stem cells: Molecular characteristics and clinical applications. World J. Stem Cells 2010;2:67-80.

196. Day TF, Guo X, Garrett-Beal L et al. Wnt/beta-catenin signaling in mesenchymal progenitors controls osteoblast and chondrocyte differentiation during vertebrate skeletogenesis. Dev Cell 2005;8: 739-750.

197. Luo Q, Kang Q, Si W et al. Connective tissue growth factor (CTGF) is regulated by Wnt and bone morphogenetic proteins signaling in osteoblast differentiation of mesenchymal stem cells. J Biol Chem 2004;279:55958-55968.

198. Si W, Kang Q, Luu HH et al. CCN1/Cyr61 is regulated by the canonical Wnt signal and plays an important role in Wnt3A-induced osteoblast differentiation of mesenchymal stem cells. Mol Cell Biol 2006;26: 2955-2964.

199. Tang N, Song WX, Luo J et al. BMP-9-induced osteogenic differentiation of mesenchymal progenitors requires functional canonical Wnt/ beta-catenin signalling. J Cell Mol Med 2009;13:2448-2464.

200. Wang J, Zhang $H$, Zhang $W$ et al. Bone morphogenetic protein-9 effectively induces osteo/odontoblastic differentiation of the reversibly immortalized stem cells of dental apical papilla. Stem Cells Dev 2014;23:1405-1416.

201. Zhang H, Wang J, Deng $F$ et al. Canonical Wnt signaling acts synergistically on BMP9-induced osteo/odontoblastic differentiation of stem cells of dental apical papilla (SCAPs). Biomaterials 2015;39: 145-154.

202. Liu J, Farmer SR. Regulating the balance between peroxisome proliferator-activated receptor gamma and beta-catenin signaling during adipogenesis. A glycogen synthase kinase 3 beta phosphorylation-defective mutant of beta-catenin inhibits expression of a subset of adipogenic genes. J Biol Chem 2004;279:45020-45027.

203. Taipaleenmaki H, Abdallah BM, AlDahmash A et al. Wnt signalling mediates the cross-talk between bone marrow derived pre-adipocytic and pre-osteoblastic cell populations. Exp Cell Res 2011;317:745-756.

204. Gao $Q$, Guo $M$, Jiang $X$ et al. A cocktail method for promoting cardiomyocyte differentiation from bone marrow-derived mesenchymal stem cells. Stem Cells Int 2014;2014:162024.
205. Alfaro MP, Pagni M, Vincent A et al. The Wnt modulator sFRP2 enhances mesenchymal stem cell engraftment, granulation tissue formation and myocardial repair. Proc Natl Acad Sci USA 2008;105: 18366-18371.

206. De Boer J, Wang HJ, Van Blitterswijk C. Effects of Wnt signaling on proliferation and differentiation of human mesenchymal stem cells. Tissue Eng 2004;10:393-401.

207. Clevers $\mathrm{H}$. The intestinal crypt, a prototype stem cell compartment Cell 2013;154:274-284.

208. Tian H, Biehs B, Warming $\mathrm{S}$ et al. A reserve stem cell population in small intestine renders Lgr5-positive cells dispensable. Nature 2011;478:255-259.

209. Yan KS, Chia LA, Li X et al. The intestinal stem cell markers Bmi1 and Lgr5 identify two functionally distinct populations. Proc Natl Acad Sci USA 2012;109:466-471.

210. Gehart $H$, Clevers $H$. Repairing organs: lessons from intestine and liver. Trends Genet 2015;31:344-351.

211. Gregorieff A, Pinto D, Begthel $\mathrm{H}$ et al. Expression pattern of Wnt signaling components in the adult intestine. Gastroenterology 2005;129:626-638.

212. Li L, Clevers H. Coexistence of quiescent and active adult stem cells in mammals. Science 2010;327:542-545.

213. Bastide P, Darido C, Pannequin J et al. Sox9 regulates cell proliferation and is required for Paneth cell differentiation in the intestinal epithelium. J Cell Biol 2007;178:635-648.

214. van der Flier LG, van Gijn ME, Hatzis $P$ et al. Transcription factor achaete scute-like 2 controls intestinal stem cell fate. Cell 2009;136: 903-912.

215. Batlle E, Henderson JT, Beghtel $\mathrm{H}$ et al. Beta-catenin and TCF mediate cell positioning in the intestinal epithelium by controlling the expression of EphB/ephrinB. Cell 2002;111:251-263.

216. Tian H, Biehs B, Chiu C et al. Opposing activities of Notch and Wnt signaling regulate intestinal stem cells and gut homeostasis. Cell Rep 2015;11:33-42.

217. Nostro MC, Cheng X, Keller GM et al. Wnt, activin, and BMP signaling regulate distinct stages in the developmental pathway from embryonic stem cells to blood. Cell Stem Cell 2008;2:60-71.

218. Luis TC, Weerkamp F, Naber BA et al. Wnt3a deficiency irreversibly impairs hematopoietic stem cell self-renewal and leads to defects in progenitor cell differentiation. Blood 2009;113:546-554.

219. Zhao C, Blum J, Chen A et al. Loss of beta-catenin impairs the renewal of normal and CML stem cells in vivo. Cancer Cell 2007;12:528-541.

220. Schaniel C, Sirabella D, Qiu J et al. Wnt-inhibitory factor 1 dysregulation of the bone marrow niche exhausts hematopoietic stem cells. Blood 2011;118:2420-2429.

221. Reya $T$, Duncan AW, Ailles $L$ et al. A role for Wnt signalling in selfrenewal of haematopoietic stem cells. Nature 2003;423:409-414.

222. Fukuda S, Pelus LM. Regulation of the inhibitor-of-apoptosis family member survivin in normal cord blood and bone marrow CD34(+) cells by hematopoietic growth factors: implication of survivin expression in normal hematopoiesis. Blood 2001;98: 2091-2100.

223. Gurbuxani $\mathrm{S}, \mathrm{Xu} \mathrm{Y}$, Keerthivasan $\mathrm{G}$ et al. Differential requirements for survivin in hematopoietic cell development. Proc Natl Acad Sci USA 2005;102:11480-11485.

224. Clements WK, Kim AD, Ong KG et al. A somitic Wnt16/Notch pathway specifies haematopoietic stem cells. Nature 2011;474:220-224.

225. Loeffler D, Kokkaliaris KD, Schroeder T. Wnt to notch relay signaling induces definitive hematopoiesis. Cell Stem Cell 2011;9:2-4.

226. Singbrant $\mathrm{S}$, Karlsson G, Ehinger $M$ et al. Canonical BMP signaling is dispensable for hematopoietic stem cell function in both adult and fetal liver hematopoiesis, but essential to preserve colon architecture. Blood 2010;115:4689-4698.

227. Fuchs E. Scratching the surface of skin development. Nature 2007:445:834-842.

228. Lim X, Nusse R. Wnt signaling in skin development, homeostasis, and disease. Cold Spring Harb Perspect Biol 2013;5:pii: a008029.

229. DasGupta R, Fuchs E. Multiple roles for activated LEF/TCF transcription complexes during hair follicle development and differentiation. Development 1999;126:4557-4568.

230. Huelsken J, Vogel R, Erdmann B et al. beta-Catenin controls hair follicle morphogenesis and stem cell differentiation in the skin. Cell 2001;105:533-545. 
231. Nguyen $\mathrm{H}$, Merrill BJ, Polak L et al. Tcf3 and Tcf4 are essential for longterm homeostasis of skin epithelia. Nat Genet 2009;41:1068-1075.

232. Lien $\mathrm{WH}$, Polak $\mathrm{L}$, Lin $\mathrm{M}$ et al. In vivo transcriptional governance of hair follicle stem cells by canonical Wnt regulators. Nat Cell Biol 2014;16:179-190.

233. Sun $\mathrm{P}$, Watanabe $\mathrm{K}$, Fallahi $\mathrm{M}$ et al. Pygo2 regulates beta-catenininduced activation of hair follicle stem/progenitor cells and skin hyperplasia. Proc Natl Acad Sci USA 2014;111:10215-10220.

234. Kandyba E, Leung Y, Chen YB et al. Competitive balance of intrabulge BMP/Wnt signaling reveals a robust gene network ruling stem cell homeostasis and cyclic activation. Proc Natl Acad Sci USA 2013;110: 1351-1356.

235. Kandyba E, Kobielak K. Wnt7b is an important intrinsic regulator of hair follicle stem cell homeostasis and hair follicle cycling. Stem Cells 2014;32:886-901.

236. Nusse R, van Ooyen A, Cox D et al. Mode of proviral activation of a putative mammary oncogene (int-1) on mouse chromosome 15 . Nature 1984;307:131-136.

237. Korinek V, Barker N, Morin PJ et al. Constitutive transcriptional activation by a beta-catenin-Tcf complex in APC-/- colon carcinoma. Science 1997;275:1784-1787.

238. Morin PJ, Sparks $A B$, Korinek $V$ et al. Activation of beta-catenin-Tcf signaling in colon cancer by mutations in beta-catenin or APC. Science 1997;275:1787-1790.

239. Kinzler KW, Vogelstein B. Lessons from hereditary colorectal cancer. Cell 1996;87:159-170.

240. Kinzler KW, Vogelstein B. Landscaping the cancer terrain. Science 1998;280:1036-1037.

241. Clements WM, Lowy AM, Groden J. Adenomatous polyposis coli/betacatenin interaction and downstream targets: altered gene expression in gastrointestinal tumors. Clin Colorectal Cancer 2003;3:113-120.

242. Su LK, Kinzler KW, Vogelstein B et al. Multiple intestinal neoplasia caused by a mutation in the murine homolog of the APC gene. Science 1992;256:668-670.

243. Miyoshi Y, Iwao K, Nagasawa $Y$ et al. Activation of the beta-catenin gene in primary hepatocellular carcinomas by somatic alterations involving exon 3. Cancer Res 1998;58:2524-2527.

244. Satoh S, Daigo Y, Furukawa Y et al. AXIN1 mutations in hepatocellular carcinomas, and growth suppression in cancer cells by virusmediated transfer of AXIN1. Nat Genet 2000;24:245-250.

245. Polakis P. The many ways of Wnt in cancer. Curr Opin Genet Dev 2007;17:45-51.

246. Zhang Y, Morris JPt, Yan W et al. Canonical wnt signaling is required for pancreatic carcinogenesis. Cancer Res 2013;73:4909-4922.

247. Xie D, Xie K. Pancreatic cancer stromal biology and therapy. Genes Dis 2015;2:133-143.

248. Yu M, Ting DT, Stott SL et al. RNA sequencing of pancreatic circulating tumour cells implicates WNT signalling in metastasis. Nature 2012;487:510-513.

249. Haydon RC, Deyrup A, Ishikawa A et al. Cytoplasmic and/or nuclear accumulation of the beta-catenin protein is a frequent event in human osteosarcoma. Int J Cancer 2002;102:338-342.

250. Hoffmeyer K, Raggioli A, Rudloff $\mathrm{S}$ et al. Wnt/beta-catenin signaling regulates telomerase in stem cells and cancer cells. Science 2012;336: 1549-1554.

251. Wissmann C, Wild PJ, Kaiser S et al. WIF1, a component of the Wnt pathway, is down-regulated in prostate, breast, lung, and bladder cancer. J Pathol 2003;201:204-212.

252. Kansara $M$, Tsang $M$, Kodjabachian $L$ et al. Wnt inhibitory factor 1 is epigenetically silenced in human osteosarcoma, and targeted disruption accelerates osteosarcomagenesis in mice. J Clin Invest 2009;119:837-851

253. Augustin I, Goidts V, Bongers A et al. The Wnt secretion protein Evi/ Gpr177 promotes glioma tumourigenesis. EMBO Mol Med 2012;4:38-51.

254. Maruyama EO, Yu HM, Jiang $M$ et al. Gpr177 deficiency impairs mammary development and prohibits Wnt-induced tumorigenesis. PLoS One 2013;8:e56644.

255. Voloshanenko O, Erdmann G, Dubash TD et al. Wnt secretion is required to maintain high levels of Wnt activity in colon cancer cells. Nat Commun 2013;4:2610.

256. Both J, Krijgsman O, Bras J et al. Focal chromosomal copy number aberrations identify CMTM8 and GPR177 as new candidate driver genes in osteosarcoma. PLoS One 2014;9:e115835.
257. Chiou SS, Wang LT, Huang SB et al. Wntless (GPR177) expression correlates with poor prognosis in B-cell precursor acute lymphoblastic leukemia via Wnt signaling. Carcinogenesis 2014;35: 2357-2364.

258. Stewart J, James J, McCluggage GW et al. Analysis of wntless (WLS) expression in gastric, ovarian, and breast cancers reveals a strong association with HER2 overexpression. Mod Pathol 2015;28: 428-436.

259. Mullighan CG, Zhang J, Kasper LH et al. CREBBP mutations in relapsed acute lymphoblastic leukaemia. Nature 2011;471:235-239.

260. Rosenbluh J, Nijhawan D, Cox AG et al. beta-Catenin-driven cancers require a YAP1 transcriptional complex for survival and tumorigenesis. Cell 2012;151:1457-1473.

261. Mehlen P, Puisieux A. Metastasis: a question of life or death. Nat Rev Cancer 2006;6:449-458.

262. Coghlin C, Murray Gl. Current and emerging concepts in tumour metastasis. J Pathol 2010;222:1-15.

263. Heuberger J, Birchmeier W. Interplay of cadherin-mediated cell adhesion and canonical Wnt signaling. Cold Spring Harb Perspect Biol 2010;2:a002915

264. Cathcart J, Pulkoski-Gross A, Cao J. Targeting matrix metalloproteinases in cancer: bringing new life to old ideas. Genes Dis 2015;2: 26-34.

265. Vermeulen L, De Sousa EMF, van der Heijden $M$ et al. Wnt activity defines colon cancer stem cells and is regulated by the microenvironment. Nat Cell Biol 2010;12:468-476.

266. Lamouille $\mathrm{S}, \mathrm{Xu}$ J, Derynck R. Molecular mechanisms of epithelialmesenchymal transition. Nat Rev Mol Cell Biol 2014;15:178-196.

267. Gonzalez DM, Medici D. Signaling mechanisms of the epithelialmesenchymal transition. Sci Signal 2014;7:re8.

268. Nguyen DX, Chiang AC, Zhang XH et al. WNT/TCF signaling through LEF1 and HOXB9 mediates lung adenocarcinoma metastasis. Cell 2009;138:51-62.

269. Previdi S, Maroni P, Matteucci E et al. Interaction between humanbreast cancer metastasis and bone microenvironment through activated hepatocyte growth factor/Met and beta-catenin/Wnt pathways. Eur J Cancer 2010;46:1679-1691.

270. Yang L, Tang $H$, Kong $Y$ et al. LGR5 promotes breast cancer progression and maintains stem-like cells through activation of Wnt/beta-catenin signaling. Stem Cells 2015;33:2913-2924.

271. Kawaguchi-Ihara N, Murohashi I, Nara $\mathrm{N}$ et al. Promotion of the self-renewal capacity of human acute leukemia cells by Wnt3A. Anticancer Res 2008;28:2701-2704.

272. Bisson I, Prowse DM. WNT signaling regulates self-renewal and differentiation of prostate cancer cells with stem cell characteristics. Cell Res 2009;19:683-697.

273. Molejon MI, Tellechea Jl, Moutardier V et al. Targeting CD44 as a novel therapeutic approach for treating pancreatic cancer recurrence. Oncoscience 2015;2:572-575.

274. Schulenburg A, Cech P, Herbacek I et al. CD44-positive colorectal adenoma cells express the potential stem cell markers musashi antigen (msi1) and ephrin B2 receptor (EphB2). J Pathol 2007;213: 152-160.

275. Verkaar F, Zaman GJ. New avenues to target Wnt/beta-catenin signaling. Drug Discov Today 2011;16:35-41.

276. Polakis P. Drugging Wnt signalling in cancer. Embo J 2012;31: 2737-2746.

277. Jamieson C, Sharma M, Henderson BR. Targeting the beta-catenin nuclear transport pathway in cancer. Semin Cancer Biol 2014;27: 20-29.

278. Kahn M. Can we safely target the WNT pathway? Nat Rev Drug Discov 2014;13:513-532.

279. Madan B, Virshup DM. Targeting Wnts at the source-new mechanisms, new biomarkers, new drugs. Mol Cancer Ther 2015;14:1087-1094.

280. Morin PJ, Vogelstein B, Kinzler KW. Apoptosis and APC in colorectal tumorigenesis. Proc Natl Acad Sci USA 1996;93:7950-7954.

281. Chen S, Guttridge DC, You Z et al. Wnt-1 signaling inhibits apoptosis by activating beta-catenin/T cell factor-mediated transcription. J Cell Biol 2001;152:87-96.

282. He B, You L, Uematsu K et al. A monoclonal antibody against Wnt-1 induces apoptosis in human cancer cells. Neoplasia 2004;6:7-14.

283. Mikami I, You L, He B et al. Efficacy of Wnt-1 monoclonal antibody in sarcoma cells. BMC Cancer 2005;5:53. 
284. Wei W, Chua MS, Grepper S et al. Blockade of Wnt-1 signaling leads to anti-tumor effects in hepatocellular carcinoma cells. Mol Cancer 2009;8:76.

285. Lavergne E, Hendaoui I, Coulouarn C et al. Blocking Wnt signaling by SFRP-like molecules inhibits in vivo cell proliferation and tumor growth in cells carrying active beta-catenin. Oncogene 2011;30:423-433.

286. Rubin EM, Guo Y, Tu K et al. Wnt inhibitory factor 1 decreases tumorigenesis and metastasis in osteosarcoma. Mol Cancer Ther 2010;9:731-741.

287. Horvath LG, Henshall SM, Kench JG et al. Membranous expression of secreted frizzled-related protein 4 predicts for good prognosis in localized prostate cancer and inhibits PC3 cellular proliferation in vitro. Clin Cancer Res 2004;10:615-625.

288. Joesting MS, Perrin S, Elenbaas B et al. Identification of SFRP1 as a candidate mediator of stromal-to-epithelial signaling in prostate cancer. Cancer Res 2005;65:10423-10430.

289. DeAlmeida VI, Miao L, Ernst JA et al. The soluble wnt receptor Frizzled8CRD-hFc inhibits the growth of teratocarcinomas in vivo. Cancer Res 2007;67:5371-5379.

290. Wei W, Chua MS, Grepper S et al. Soluble Frizzled-7 receptor inhibits Wnt signaling and sensitizes hepatocellular carcinoma cells towards doxorubicin. Mol Cancer 2011;10:16.

291. Nambotin SB, Lefrancois L, Sainsily X et al. Pharmacological inhibition of Frizzled-7 displays anti-tumor properties in hepatocellular carcinoma. J Hepatol 2011;54:288-299.

292. Shin H, Kim JH, Lee YS et al. Change in gene expression profiles of secreted frizzled-related proteins (SFRPs) by sodium butyrate in gastric cancers: induction of promoter demethylation and histone modification causing inhibition of Wnt signaling. Int J Oncol 2012;40: 1533-1542.

293. Shan J, Shi DL, Wang J et al. Identification of a specific inhibitor of the dishevelled PDZ domain. Biochemistry 2005;44:15495-15503.

294. Fujii N, You L, Xu Z et al. An antagonist of dishevelled protein-protein interaction suppresses beta-catenin-dependent tumor cell growth. Cancer Res 2007;67:573-579.

295. Grandy D, Shan J, Zhang X et al. Discovery and characterization of a small molecule inhibitor of the PDZ domain of dishevelled. J Biol Chem 2009;284:16256-16263.

296. Huang SM, Mishina YM, Liu S et al. Tankyrase inhibition stabilizes axin and antagonizes Wnt signalling. Nature 2009;461:614-620.

297. Chen B, Dodge ME, Tang W et al. Small molecule-mediated disruption of Wnt-dependent signaling in tissue regeneration and cancer. Nat Chem Biol 2009;5:100-107.

298. Waaler J, Machon O, Tumova L et al. A novel tankyrase inhibitor decreases canonical Wnt signaling in colon carcinoma cells and reduces tumor growth in conditional APC mutant mice. Cancer Res 2012;72:2822-2832.

299. Lau T, Chan E, Callow M et al. A novel tankyrase small-molecule inhibitor suppresses APC mutation-driven colorectal tumor growth. Cancer Res 2013;73:3132-3144.

300. Lehtio L, Chi NW, Krauss S. Tankyrases as drug targets. FEBS J 2013;280:3576-3593.

301. Liu J, Pan S, Hsieh MH et al. Targeting Wnt-driven cancer through the inhibition of Porcupine by LGK974. Proc Natl Acad Sci USA 2013;110: 20224-20229.

302. Kabiri Z, Greicius G, Madan B et al. Stroma provides an intestinal stem cell niche in the absence of epithelial Wnts. Development 2014;141: 2206-2215.

303. Lepourcelet M, Chen YN, France DS et al. Small-molecule antagonists of the oncogenic Tcf/beta-catenin protein complex. Cancer Cell 2004;5:91-102

304. Wei W, Chua MS, Grepper S et al. Small molecule antagonists of Tcf4/ beta-catenin complex inhibit the growth of HCC cells in vitro and in vivo. Int J Cancer 2010;126:2426-2436.

305. Minke KS, Staib P, Puetter A et al. Small molecule inhibitors of WNT signaling effectively induce apoptosis in acute myeloid leukemia cells. Eur J Haematol 2009;82:165-175.

306. Chen Z, Venkatesan AM, Dehnhardt CM et al. 2,4-Diaminoquinazolines as inhibitors of beta-catenin/Tcf-4 pathway: Potential treatment for colorectal cancer. Bioorg Med Chem Lett 2009;19: 4980-4983.

307. Gonsalves FC, Klein K, Carson BB et al. An RNAi-based chemical genetic screen identifies three small-molecule inhibitors of the
Wnt/wingless signaling pathway. Proc Natl Acad Sci USA 2011;108: 5954-5963.

308. Trosset JY, Dalvit C, Knapp S et al. Inhibition of protein-protein interactions: the discovery of druglike beta-catenin inhibitors by combining virtual and biophysical screening. Proteins 2006;64:60-67.

309. Tian W, Han X, Yan M et al. Structure-based discovery of a nove inhibitor targeting the beta-catenin/Tcf4 interaction. Biochemistry 2012;51:724-731.

310. Yao H, Ashihara E, Strovel JW et al. AV-65, a novel Wnt/beta-catenin signal inhibitor, successfully suppresses progression of multiple myeloma in a mouse model. Blood Cancer J 2011;1:e43.

311. Takada K, Zhu D, Bird GH et al. Targeted disruption of the BCL9/betacatenin complex inhibits oncogenic Wnt signaling. Sci Transl Med 2012;4:148ra117.

312. Grossmann TN, Yeh JT, Bowman BR et al. Inhibition of oncogenic Wnt signaling through direct targeting of beta-catenin. Proc Natl Acad Sci USA 2012;109:17942-17947.

313. Emami $\mathrm{KH}$, Nguyen $\mathrm{C}, \mathrm{Ma} \mathrm{H}$ et al. A small molecule inhibitor of beta-catenin/CREB-binding protein transcription [corrected]. Proc Natl Acad Sci USA 2004;101:12682-12687.

314. Eguchi M, Nguyen C, Lee SC et al. ICG-001, a novel small molecule regulator of TCF/beta-catenin transcription. Med Chem 2005;1: 467-472.

315. Miyabayashi T, Teo JL, Yamamoto $M$ et al. Wnt/beta-catenin/CBP signaling maintains long-term murine embryonic stem cell pluripotency. Proc Natl Acad Sci USA 2007;104:5668-5673.

316. Hasegawa K, Yasuda SY, Teo JL et al. Wht signaling orchestration with a small molecule DYRK inhibitor provides long-term xeno-free human pluripotent cell expansion. Stem Cells Transl Med 2012;1: $18-28$.

317. Marson A, Foreman R, Chevalier B et al. Wnt signaling promotes reprogramming of somatic cells to pluripotency. Cell Stem Cell 2008;3:132-135.

318. Wend $\mathrm{P}$, Fang $\mathrm{L}$, Zhu $\mathrm{Q}$ et al. Wnt/beta-catenin signalling induces MLL to create epigenetic changes in salivary gland tumours. EMBO J 2013;32:1977-1989.

319. Gang EJ, Hsieh YT, Pham J et al. Small-molecule inhibition of $\mathrm{CBP} /$ catenin interactions eliminates drug-resistant clones in acute lymphoblastic leukemia. Oncogene 2014;33:2169-2178.

320. He K, Xu T, Xu Y et al. Cancer cells acquire a drug resistant, highly tumorigenic, cancer stem-like phenotype through modulation of the PI3K/Akt/beta-catenin/CBP pathway. Int J Cancer 2014;134: 43-54.

321. Lenz HJ, Kahn M. Safely targeting cancer stem cells via selective catenin coactivator antagonism. Cancer Sci 2014;105:1087-1092.

322. Smith ML, Hawcroft G, Hull MA. The effect of non-steroidal antiinflammatory drugs on human colorectal cancer cells: evidence of different mechanisms of action. Eur J Cancer 2000;36:664-674.

323. Dihlmann S, Siermann A, von Knebel Doeberitz M. The nonsteroidal anti-inflammatory drugs aspirin and indomethacin attenuate betacatenin/TCF-4 signaling. Oncogene 2001;20:645-653.

324. Zhou L, An N, Haydon RC et al. Tyrosine kinase inhibitor STI-571/ Gleevec down-regulates the beta-catenin signaling activity. Cancer Lett 2003;193:161-170.

325. Christensen JG, Schreck R, Burrows J et al. A selective small molecule inhibitor of c-Met kinase inhibits c-Met-dependent phenotypes in vitro and exhibits cytoreductive antitumor activity in vivo. Cancer Res 2003;63:7345-7355.

326. Baryawno N, Sveinbjornsson B, Eksborg S et al. Small-molecule inhibitors of phosphatidylinositol 3-kinase/Akt signaling inhibit Wnt/beta-catenin pathway cross-talk and suppress medulloblastoma growth. Cancer Res 2010;70:266-276.

327. Pendas-Franco N, Aguilera O, Pereira F et al. Vitamin D and Wnt/betacatenin pathway in colon cancer: role and regulation of DICKKOPF genes. Anticancer Res 2008;28:2613-2623.

328. Jaiswal AS, Marlow BP, Gupta N et al. Beta-catenin-mediated transactivation and cell-cell adhesion pathways are important in curcumin (diferuylmethane)-induced growth arrest and apoptosis in colon cancer cells. Oncogene 2002;21:8414-8427.

329. Kim J, Zhang X, Rieger-Christ KM et al. Suppression of Wnt signaling by the green tea compound (-)-epigallocatechin 3-gallate (EGCG) in invasive breast cancer cells. Requirement of the transcriptional repressor HBP1. J Biol Chem 2006;281:10865-10875. 
330. Park $\mathrm{CH}$, Chang JY, Hahm ER et al. Quercetin, a potent inhibitor against beta-catenin/Tcf signaling in SW480 colon cancer cells. Biochem Biophys Res Commun 2005;328:227-234.

331. Roccaro AM, Leleu X, Sacco A et al. Resveratrol exerts antiproliferative activity and induces apoptosis in Waldenstrom's macroglobulinemia. Clin Cancer Res 2008;14:1849-1858.

332. He BC, Gao JL, Luo X et al. Ginsenoside Rg3 inhibits colorectal tumor growth through the down-regulation of Wnt/ss-catenin signaling. Int J Oncol 2011;38:437-445.

333. He BC, Gao JL, Zhang BQ et al. Tetrandrine inhibits Wnt/beta-catenin signaling and suppresses tumor growth of human colorectal cancer. Mol Pharmacol 2011;79:211-219.

334. Lu W, Lin C, King TD et al. Silibinin inhibits Wnt/beta-catenin signaling by suppressing Wnt co-receptor LRP6 expression in human prostate and breast cancer cells. Cell Signal 2012;24:2291-2296.

335. Lu W, Lin C, Li Y. Rottlerin induces Wnt co-receptor LRP6 degradation and suppresses both Wnt/beta-catenin and mTORC1 signaling in prostate and breast cancer cells. Cell Signal 2014;26:1303-1309.

336. Thorne CA, Hanson AJ, Schneider J et al. Small-molecule inhibition of Wnt signaling through activation of casein kinase 1alpha. Nat Chem Biol 2010;6:829-836.

337. Chen M, Wang J, Lu J et al. The anti-helminthic niclosamide inhibits Wnt/Frizzled1 signaling. Biochemistry 2009;48:10267-10274.

338. Lu W, Lin C, Roberts MJ et al. Niclosamide suppresses cancer cell growth by inducing Wnt co-receptor LRP6 degradation and inhibiting the Wnt/beta-catenin pathway. PLoS One 2011;6:e29290.
339. Osada T, Chen M, Yang XY et al. Antihelminth compound niclosamide downregulates Wnt signaling and elicits antitumor responses in tumors with activating APC mutations. Cancer Res 2011;71: 4172-4182.

340. Arend RC, Londono-Joshi Al, Samant RS et al. Inhibition of Wnt/betacatenin pathway by niclosamide: a therapeutic target for ovarian cancer. Gynecol Oncol 2014;134:112-120.

341. Liu C, Lou W, Armstrong C et al. Niclosamide suppresses cell migration and invasion in enzalutamide resistant prostate cancer cells via Stat3-AR axis inhibition. Prostate 2015;75:1341-1353.

342. Liu C, Lou W, Zhu Y et al. Niclosamide inhibits androgen receptor variants expression and overcomes enzalutamide resistance in castration-resistant prostate cancer. Clin Cancer Res 2014;20: 3198-3210.

343. Londono-Joshi Al, Arend RC, Aristizabal L et al. Effect of niclosamide on basal-like breast cancers. Mol Cancer Ther 2014;13:800-811.

344. Liao Z, Nan G, Yan Z et al. The anthelmintic drug niclosamide inhibits the proliferative activity of human osteosarcoma cells by targeting multiple signal pathways. Curr Cancer Drug Targets 2015;15:726-738.

345. Lu D, Choi MY, Yu J et al. Salinomycin inhibits Wnt signaling and selectively induces apoptosis in chronic lymphocytic leukemia cells. Proc Natl Acad Sci USA 2011;108:13253-13257.

346. Tumova L, Pombinho AR, Vojtechova $M$ et al. Monensin inhibits canonical Wnt signaling in human colorectal cancer cells and suppresses tumor growth in multiple intestinal neoplasia mice. Mol Cancer Ther 2014;13:812-822. 